\title{
Consequências da Ação antidumping sobre a produção de camarão na microrregião do Litoral de Aracati - CE, na perspectiva dos elos da cadeia produtiva
}

Consequences of antidumping action on shrimp production in the microregion of Aracati's litoral - Ceará, in perspective of the production chain links

\author{
Antonio Kaminski Alvez ${ }^{1}$ \\ Mirian Beatriz Schneider Braun
}

Artigo recebido em para publicação em mai/2013 e aceito para publicação em jun/2013

\section{Resumo}

O presente artigo é parte da dissertação de mestrado: Ação Antidumping ( $A D)$ : produção de camarão em cativeiro e Desenvolvimento Regional na microrregião do Litoral de Aracati - CE, defendida no Programa de Pós Graduação em Desenvolvimento Regional e agronegócio da Unioeste/PR. A dissertação como um todo discutiu os impactos causados pala ação antidumping imposta aos produtores de camarão brasileiros pela indústria de pesca norte Americana, assim como seus efeitos sobre o desenvolvimento econômico para a microrregião litoral de Aracati - CE. O objetivo desse trabalho é apresentar os resultados dos questionários aplicados aos produtores de camarão, que apresentam as impressões dos produtores sobre os efeitos da $A D$ sobre os empreendimentos e os impactos sobre a especialização na produção, mapeados através do Coeficiente locacional. Fica claro, que a produção foi afetada pela $A D$, reduzindo as exportações destinadas aos EUA à praticamente zero e que o setor passou a direcionar suas produção ao Mercado interno, em franco crescimento no period avaliado. No entanto, apareceram outros problemas importantes, como ausência de política de defesa do setor em relação a OMC, e de políticas que facilitassem o desenvolvimento do setor como um todo.

Palavras-chaves: Ação Antidumping. Camarão. Desenvolvimento Regional. Políticas setoriais.

\section{Abstract}

This article is part of the master dissertation: Antidumping Action (AD): production of farmed shrimp and Regional Development in the coast of Aracati - CE, defended in the Graduate Program in Regional Development and agribusiness at Unioeste / PR. The dissertation discussed the impacts of antidumping action imposed by the North American fishing industry at the Brazilian shrimp producers, as well as its effects on economic development for coastal micro area of Aracati - CE. The aim of this paper is to present the results of questionnaires aplied to shrimp producers, featuring the prints of the producers on the effects of $A D$ on the developments. It is clear that the production was affected by $A D$, reducing the exportation to the U.S. to virtually zero and that the industry began to direct their production to the domestic market, significant growth in assessed period. However, others important problems appeared, as the absence of defense policy in the sector in relation to the WTO, and policies that facilitate the development of the sector as a whole.

Key Words: Antidumping Action. Shrimp. Regional Developmen. Sectorial politics.

\footnotetext{
${ }^{1}$ Antonio kaminski Alvez: Administrador pela FVJ - Faculdade do Vale do Jaguaribe. Mestre em Desenvolvimento Regional e Agronegócio pela Unioeste - Campus de Toledo/PR. e-mail: antkaminski@gamil.com

Mirian Beatriz Schneider Braun: Economista pela Unioeste, Mestre em Desenvolvimento Econômico pela Universidade Federal do Paraná - UFPR. Doutora em História Econômica pela Universidade de León- Espanha e Pós Doutora em Economia Aplicada pela ESALQ/USP. Professora Associada Do Curso de Ciências Econômicas e do Programa de Pós Graduação em Desenvolvimento Regional e Agronegócio. Pesquisadora do GEPEC - Grupo de Pesquisa em Desenvolvimento Regional e Agronegócio. e-mail: mirian-braun@hotmail.com
} 


\section{Introdução}

O presente artigo é parte da dissertação de mestrado: Ação Antidumping: produção de camarão em cativeiro e Desenvolvimento Regional na microrregião do Litoral de Aracati - CE, defendida no Programa de Pós Graduação em Desenvolvimento Regional e agronegócio da Unioeste/PR. A dissertação como um todo discutiu os impactos causados pala ação antidumping imposta aos produtores de camarão brasileiros pela indústria de pesca norte Americana, assim como seus efeitos sobre o desenvolvimento econômico para a microrregião litoral de Aracati - CE. Como fica evidente, o trabalho foi bastante abrangente, e aqui apresentaremos apenas os resultados da pesquisa de campo, composta por questionários aplicados aos setores envolvidos com a produção de camarão na região.

Foram desenvolvidos e aplicados quatro questionários, um dos quais tomou como informante o presidente da $A B C C(2010)$, visando obter um parecer de ordem institucional sobre a atuação dos órgãos governamentais quanto à ação antidumping, e assim caracterizar os efeitos da ação para o setor e para o desenvolvimento regional.

Os demais questionários estão voltados para os elos da cadeia produtiva, e a proposição era pesquisar: a) dos laboratórios de produção de pós larvas - a quantidade de funcionários nos marcos 2003-2010; efeitos sobre a produção causados por elementos internos ou externos; observar se os níveis de produção e comercialização foram afetados pela falta de compradores ou pela escassez do produto. b) Das fazendas de criação e engorda - verificar a quantidade de empregos durante o período compreendido entre 2003 a 2010; quais os fatores que influenciaram na queda de produção (dumping, doenças, enchentes, comercialização da produção); verificar demanda de compradores, local/regional, nacional ou mercado externo. c) Da indústria processadora/exportador - verificar o nível de emprego; avaliar se a produção foi afetado pela oferta ou pela demanda, ou ainda pela falta de novos mercados consumidores; verificar se o escoamento da produção ocorreu pelo mercado nacional ou internacional e em que proporção/porcentagem. Com relação ao total exportado, verificar qual o percentual foi destinado para o mercado do EUA e demais destinos. Mas antes de avaliarmos mais profundamente os resultados de tais questionários, apresenta-se uma visão geral do setor em estudo.

\section{Panorama da carcinicultura nacional e no estado do ceará}

A Carcinicultura no Brasil teve início na década de 1970 no Estado do Rio Grande do Norte, como alternativa para substituição da exploração de sal, conforme dados da (ABCC, 2010). Como resultado de pesquisas na busca de espécies adequadas, ocorreu o aumento da produção e partir daí novos investimentos, e aumento das áreas de produção, bem como da produtividade em decorrência da aplicação de novas tecnologias. O gráfico 1(abaixo) evidencia isso em três aspectos, primeiro por intermédio da ascensão da produção, segundo pelo aumento da área cultivada e em terceiro 0 significativo aumento da produtividade. $\mathrm{O}$ ano de 2003 foi o ápice da atividade até então, nesse ano, chegou-se a marca de 90.190 toneladas produzidas, a implementação de 16.598 ha de área produtiva, bem como uma produtividade média recorde de $6.084 \mathrm{~kg} / \mathrm{ha} / \mathrm{ano}$.

No entanto, a partir de 2004 ocorre uma queda de produtividade, e como consequência, a redução da produção e da área cultivada. No ano de 2005 tem início à cobrança da tarifa antidumping imposta ao setor. Percebe-se então uma queda na produção em relação ao ano anterior, fixando uma marca de 65.000 toneladas, essa média de produção prossegue estável até 2009. Ainda em 2005 e 2006 houve retração na área de produção, o que pode ser parcialmente explicado por um período de insegurança causado pela ação antidumping, fato este que criou uma barreira ao principal canal de distribuição da produção nacional, que eram os EUA, aliado a outros fatores, tais como: enchentes, infecção virótica (ABCC, 2010).

Pela avaliação do gráfico 1, fica claro que o fator que mais contribuiu para a redução do volume de produção foi a queda do índice de produtividade, explicada por uma estratégia de redução induzida, por meio da diminuição da quantidade de indivíduos por $\mathrm{m}^{2}$. Um reforço para essa a adoção dessa estratégia foi a insegurança causada pela ação antidumping americana, que estabeleceu uma barreira a entrada do camarão proveniente do Brasil naquele mercado e que era, naquele momento, o principal canal de escoamento da produção nacional.

No ano de 2005, em parte em função do próprio crescimento econômico do Brasil, tem início uma reconversão do escoamento da produção para o mercado interno e a gradativa redução das exportações de modo geral. Já a queda ocorrida no período de 2008 a 2009 pode ter sido intensificada pelas 
enchentes que deterioram a qualidade da água. Para o ano de 2010 segundo a ABCC (2011) ocorreu um aumento de produtividade e da produção sem o aumento de área, superando os efeitos do fantasma da ação antidumping.

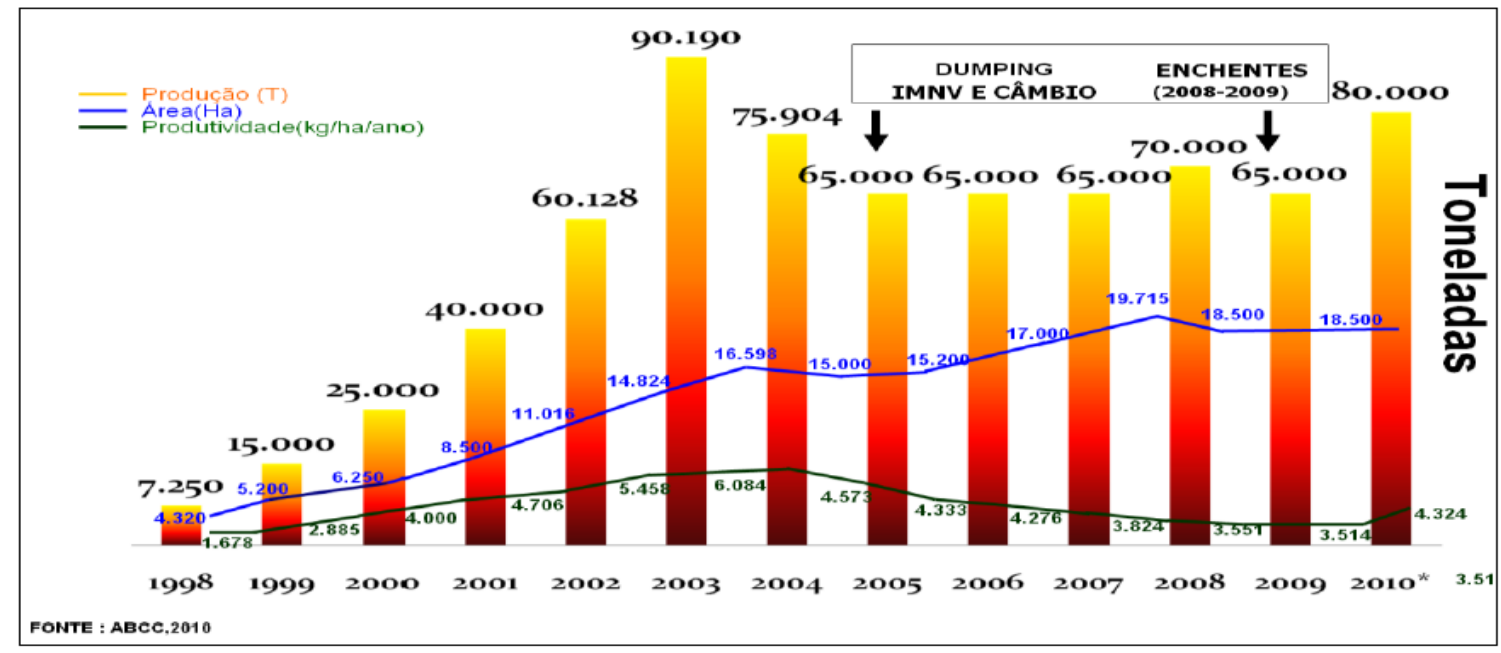

Gráfico 1 - Desempenho da Carcinicultura brasileira de 1998 a 2010 *Estimativa ABCC.

Fonte: ABCC, 2010.

É importante destacar que em 2003 o mercado externo era destino de $78 \%$ da produção nacional de camarão cultivado, e serviu de estímulo para muitos investidores que viam nessa relação com o mercado externo, uma boa fonte de retorno para seus investimentos, incentivados pela elevada taxa de câmbio. A partir do ano de 2005 o camarão brasileiro passou a ser sobretaxado em 7,05\% quando exportado para os Estados Unidos, desde então, tem início um processo inverso do destino da produção nacional, portanto, já em 2007 o mercado interno era responsável por 76\% desse consumo, e em 2010 passou a absorver 98\% do camarão produzido, (ABCC, 2010). Um dos fatores que acelerou essa reconversão para o mercado interno foi desvalorização cambial do dólar frente ao real.

Em que se pese o potencial produtivo da carcinicultura para a região Nordeste, há que se observar a inércia das instituições ambientais, a morosidade na avaliação dos projetos de licenciamento no que tange a liberação de licenças, seja de implantação, instalação ou operacional. Não se pode ficar indiferente, diante de casos, em que, um projeto passa mais de quatro anos aguardando uma análise de um técnico junto aos órgãos de licenciamento ambiental do Estado. Esses fatores, segundo conversas informais com os entrevistados, foram tão danosos ou mais, para o desenvolvimento do setor, quanto a própria ação antidumping.

Nesse sentido Tahim (2008) destaca que "no Brasil tais políticas e legislações para o setor ainda sejam muito confusas e desorganizadas, ou seja, não há uma posição institucional ou legal muito clara". Essa indefinição, muitas vezes força os produtores a agirem por conta própria e assumir o ônus da implantação de um projeto mesmo sem ter recebido as licenças ambientais, atitude que causa prejuízos e insegurança aos investidores.

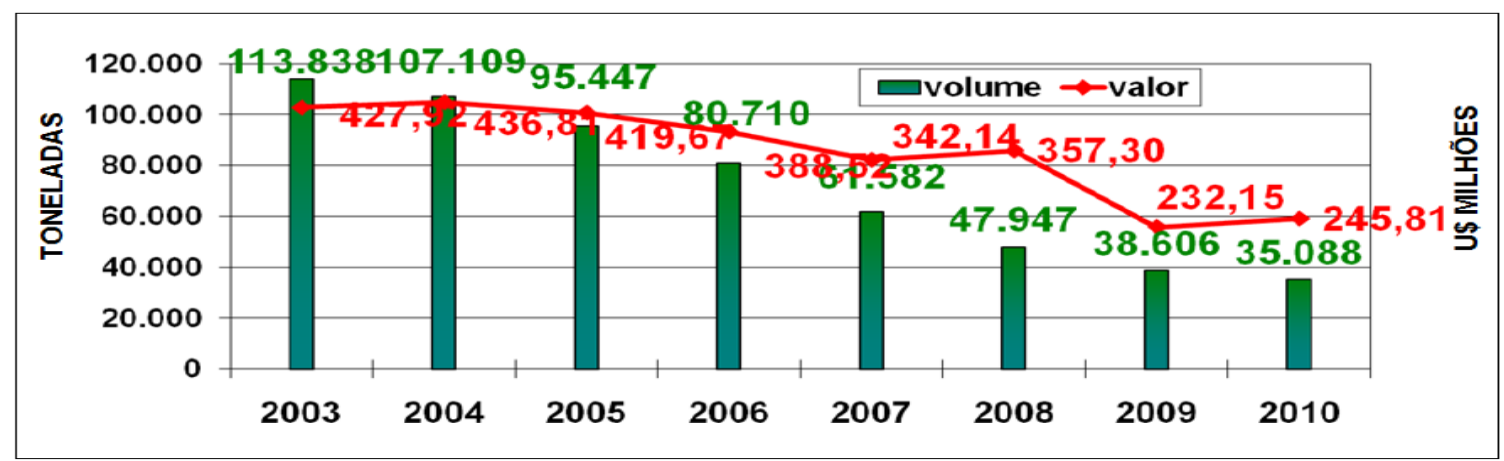

Gráfico 2 - Desempenho das exportações de pescado do Brasil em volume e valor 2003 - 2010.

Fonte: ABCC 2011. 
Voltando a produção do camarão em cativeiro no Estado do Ceará, destaca-se que no ano de 2003 o Ceará foi responsável $29 \%$ da produção nacional, ao contribuir com $34,43 \%$ das exportações totais, e contava com 3.367 hectares de área em produção, distribuídos em 185 projetos instalados. No ano de 2004 , o Estado foi responsável por $26 \%$ de todo o camarão produzido em cativeiro no país, participou com $31,74 \%$ das exportações totais, e contava com 191 produtores em 3.804 hectares de área em produção.

Para os anos de 2005 e 2006 respectivamente, o Ceará exportou 36,16\% e 42,61\%, período em que atingiu o maior percentual de contribuição, apesar do volume total em toneladas estar em ascensão, ressalta-se ainda, que, devido aos fatores já mencionados anteriormente, a conversão para o mercado interno, fez com que esse índice caísse para menos de 0,5\% em 2010. O Estado do Ceará assumiu a liderança da produção desse setor, com uma produção de 30.000 toneladas em 2010, conforme dados obtidos, a partir do questionário respondido pelo presidente da ABCC.

Em termos de estado os dados evidenciavam a importância do camarão para o Estado, sendo que este figura na lista dos principais produtos de exportação do Estado do Ceara, produzida pela MDIC/SECEX (2011) em segunda posição, ao gerar um volume FOB de US\$ 80.944.384 em 2003.

Depois desse período tem início uma queda na participação do produto para a balança comercial daquele Estado: em 2004, US\$ 65.187.775 4a colocação, em 2005 US\$ 57.069.881 5ำ colocação, em 2006 US\$ 48.008.047 6 a $^{\text {a }}$ colocação, em 2007 houve uma queda brusca para US\$16.656.748 16 colocação, em 2008 US\$ 9.242.549 29a colocação, em 2009 US\$2.363.074 45ª colocação, já em 2010 o produto não contava na lista.

\section{A acusação de dumping nas exportações de camarão brasileiro}

A Carcinicultura brasileira apresentou uma evolução acima da média mundial no período de 1997 a 2003 , com um crescimento médio de $71 \%$ partindo de 3.600 t para 90.180 t respectivamente (ROCHA, 2007). O aperfeiçoamento das técnicas de cultivo, a inovação tecnológica nos equipamentos, o desenvolvimento de dietas diferenciadas para cada ciclo do cultivo, aliado as condições edafoclimáticas características da região Nordeste, são alguns dos fatores que contribuíram para melhorar o desempenho e a competitividade da carcinicultura no Brasil.

Diante disso, a atividade de cultivo de camarão em cativeiro no Brasil tornou-se extremamente competitiva, e rapidamente conquistou o mercado internacional, e logo, encontrou no mercado Americano, seu maior canal de distribuição. Os dados da tabela 2 demonstram que, no ano de 2003 o Brasil exportou 21.800 toneladas equivalente a $24,2 \%$ da produção nacional. Esse volume equivale a $4,32 \%$ do total das importações de camarão efetuados pelos Estados Unidos, corresponde a oitava posição no ranking dos exportadores para o mercado Norte Americano.

\begin{tabular}{|c|c|c|c|c|c|c|c|}
\hline \multirow{2}{*}{ PAÍSES } & \multicolumn{3}{|l|}{2003} & \multicolumn{3}{|l|}{2007} & \multirow{2}{*}{\begin{tabular}{|ll}
$\%$ & Var. \\
Vol. &
\end{tabular}} \\
\hline & KG & US\$ & (\%) Partic. & KG & US\$ & (\% )Partic. & \\
\hline Tailând & 133.220 .371 & 997.693 .842 & $26,41 \%$ & 188.519 .282 & 1.235 .832 .986 & $33,85 \%$ & $41,51 \%$ \\
\hline Vietnã $2^{\circ}$ & 629 & 0.390 & $11,37 \%$ & 39.298 .570 & 459.942.318 & $7,06 \%$ & $51 \%$ \\
\hline China $3^{\circ}$ & 81.000 .467 & 443.868 .896 & $16,06 \%$ & 48.792 .098 & 238.054 .117 & $8,76 \%$ & $-39,76 \%$ \\
\hline Equador $6^{\circ}$ & 34.029 .144 & 211.258 .345 & $6,75 \%$ & 59.598 .852 & 308.872 .236 & $10,70 \%$ & $75,14 \%$ \\
\hline Índia $4^{\circ}$ & 45.468 .742 & 408.907 .420 & $9,01 \%$ & 20.775 .851 & 194.749 .707 & $3,73 \%$ & $-54,31 \%$ \\
\hline Brasil $8^{\circ}$ & 21.783.427 & 6.763 .990 & $4,32 \%$ & 327 & 4.140 & $0,00 \%$ & $-100,00 \%$ \\
\hline Sub Total & 372.879 .780 & 2.753.382.883 & $73,91 \%$ & 356.984 .980 & 2.437.455.504 & $64,10 \%$ & $-4,26 \%$ \\
\hline Outros & 91.920 .264 & 683.555 .115 & $18,22 \%$ & 135.418 .727 & 970.484 .322 & $24,31 \%$ & $47,32 \%$ \\
\hline Total & 504.494 .578 & 3.760 .449 .179 & $100,00 \%$ & 556.935 .682 & 3.904 .326 .532 & $100,00 \%$ & $10,39 \%$ \\
\hline
\end{tabular}

Tabela 2 - Volume de camarão importado pelo EUA dos países envolvidos na ação antidumping, evolução 2003 - 2007 Fonte: NMFS 2011

Ainda na tabela 2, é possível observar que em 2003 os seis países acusados de dumping representavam 73,9\% das importações de camarão do mercado Norte Americano. Já no ano de 2007, esse percentual caiu para $64,1 \%$ equivalente a uma redução $9,8 \%$. 
Ainda segundo os dados, a criação de barreiras à entrada afeta o desempenho dos mercados envolvidos. Esse fato pode ser constatado no ano de 2007, dos seis países acusados de dumping, apenas a Tailândia e o Equador conseguem ampliar a participação no mercado dos Estados Unidos. Constata-se que o Brasil foi o país mais afetado pela imposição da tarifa. Vale destacar o aumento de participação dos outros países, que foi de 18,22\% em 2002 para 47,32\% em 2007 assim como, o volume total aumentou no mesmo período em 10,39\%, equivalente a média de 2,08\% ao ano.

A National Oceanic and Atmospheric Administration (NOAA, 2011), órgão federal no âmbito do Departamento de Comércio dos Estados Unidos, aponta para a quantidade de camarão importado em 2003, que atingiu a marca de 504.494 toneladas, 75.191 toneladas a mais do que a quantidade importada em 2002. Além disso, os Estados Unidos ainda enfrentam a redução da produção interna. Conforme destaca o órgão federal de comércio (NOAA, 2011), quando enfatiza que mais de $99 \%$ dos desembarques de captura das três espécies de camarão peneídeos (branco, rosa e marrom) são oriundos do Golfo do México, ademais, nos últimos anos, a média anual de desembarques das três espécies foram cerca de 150,0 milhões de libras, no entanto, desde 2002 o volume desenbarcado caiu muito, devido às condições econômicas no setor da pesca aliado a danos causado por furacão, particularmente em 2005, quando o volume de desembarque caiu para cerca de 92 milhões de libras.

Esse mesmo órgão, ressalta ainda, que a indústria de pesca dos EUA atende somente a $10 \%$ da demanda de camarão consumido pelos Norte Americanos, e que para atender o restante da demanda interna do país, é necessário importar dos países em desenvolvimento o restante.

Diante da perda de competitividade da produção nacional, uma parte da indústria de pesca de camarão dos EUA, encontra-se cada vez mais preocupada com o que eles acreditam tratar-se de práticas desleais por parte dos exportadores. Com esse pretexto, e amparados pela "Emenda Byrd", em outubro de 2002, o lobby dos pescadores de camarão do EUA, criaram a Southern Shrimp Alliance (ASS) com a finalidade de "combater a concorrência desleal na importação de camarão", para então, em dezembro de 2003, protocolar junto ao Departamento de Comércio dos Estados Unidos, uma petição, acusando seis países ${ }^{3}$ de praticar dumping em suas exportações de camarão para os EUA.

É importante destacar, que existia oposição á ação AD por parte dos distribuidores de frutos do mar, pelo mercado varejista, assim como, por outros segmentos de transformação nos Estados Unidos. Essa oposição acontecia sob a alegação de que o camarão importado gera nos EUA 100.000 empregos no setor de transformação, rendimentos adicionais estimados em mais de US \$ 2 bilhões por ano, ademais, a redução da oferta do produto, poderia gerar um aumento considerável dos preços para o consumidor final, e que a falta de competitividade advinda dos altos custos de produção da indústria pesqueira, não podem ser atenuadas por meio de tributação das importações.

Segundo a (CITAC 2011) as petições comerciais apresentadas contra importações de camarão dos seis países em desenvolvimento, foram apresentados por um pequeno segmento da indústria do camarão nacional a fim de receber milhões de dólares em taxas de juros especiais. Uma estimativa conservadora é que os pagamentos anuais sejam igual a US\$180 milhões, cerca de US $\$ 829.493$ por empresa vinculada a petição.

Os proponentes da ação antidumping, por sua vez, fazem uma contra-acusação aos distribuidores e comerciantes dos EUA, que segundo a ASS, estes, conseguem lucros excessivos ${ }^{4}$ com $_{0}$ baixo custo dos camarões importados, e sobretudo, de não repassarem essa economia para os consumidores. Ademais, a indústria de pesca dos EUA alega que esta prática foi responsável pela perda de milhares de empregos, e forçou centenas de empresa Norte Americanas a encerrar suas atividades.

A indústria de pesca do EUA acusa os seis países de praticar dumping, entretanto, Madrid (2006) assevera que os preços dos produtos agrícolas são determinados pela Urner Barry, empresa americana que estabelece semanalmente os preços de referências das importações. Nesse caso o valor é fixado de forma antecipada, definindo o preço máximo que o mercado está disposto a pagar por um determinado produto. Entretanto, o próprio mercado Americano estabelece o preço do camarão, sendo assim, 0 camarão produzido em cativeiro apresenta menor custo de produção, quando comparado com o camarão pescado no Golfo, aliado a valorização da moeda Americana, surge um mercado atrativo para os

\footnotetext{
2 "A "Emenda Byrd", em vigor desde 2000, permite que produtores dos EUA recebam recursos auferidos com a imposição de direitos antidumping ou compensatórios sobre produtos de concorrentes estrangeiros" para maiores detalhes consulte (ITAMARATI, 2011).

${ }^{3}$ Os países acusados de dumping são: Brasil, Equador, China, Índia, Vietnã e Tailândia

4 Para maiores esclarecimentos consultar (MADRID, 2006, p. 10).
} 
produtores mundiais. Diante disso, como justificar o argumento da prática de dumping, uma vez que, o preço para o camarão é preestabelecido internamente pela Urner Barry. Efetivamente, a atitude dos pescadores foi um subterfúgio para arrecadar dinheiro, e com isso minimizar o impacto da grave crise econômica em que o setor encontra-se.

A Louisiana Shrimp Association encontrou na "Emenda Byrd" uma forma de repassar para os países em desenvolvimento o ônus da pesada indústria de pesca dos Estados Unidos. O presidente de ASS, em uma declaração a imprensa admitiu a ajuda financeira dos produtores mexicanos, para em troca, ficarem fora da lista dos países acusados de dumping. Nessa mesma direção, Madrid (2006) aponta que:

[...] na feira de Frutos do Mar realizada em Boston, em março de 2004, pela primeira vez o Presidente da SSA confirmou diante do Presidente da ASDA que o México havia contribuído significativamente com fundos para financiar as ações legais impetradas contra os seis países, incluindo o Brasil, com o objetivo principal de ficar fora da lista dos países acusados (MADRID, 2006, p.8).

Isso aponta para uma prática política que ocorre na contra mão dos acordos de comércio internacional, para proteger os produtores do México, pois caso o México estivesse incluído na lista dos países acusados de dumping, os Americanos seriam vítimas da própria política antidumping, uma vez que, o camarão mexicano ao dar entrada no comércio dos Estados Unidos, também sofreria a taxação da ação. Prevalece no caso do camarão uma política estratégica de defesa econômica dos Estados Unidos, fazendo prevalecer seu poder de potência hegemônica sobre as demais economias.

Uma demonstração do poder econômico do lobby da indústria de pesca de camarão do Golfo do México, foi a utilização do método "zeroing" quando manteve a tarifa de importação de camarão proveniente da Tailândia, Brasil, China, Índia e Vietnã por mais cinco anos, a decisão ocorreu em março de 2011, sob a alegação, da necessidade de um prazo para recuperar-se das conseqüências do acidente ambiental, provocado pelo demandaram de petróleo no Golfo em 2010, bem como, das forças devastadoras dos furacões ocorridos nos últimos cinco anos.

Do lado brasileiro, decorrido todo o prazo hábil, o Brasil consegui o direito de "retaliar" produtos de importação advindos dos Estados Unidos, para isso, deve em conformidade com o laudo do painel, reapresentar o pedido de autorização. Segundo o Itamaraty (2011) o Órgão de Solução de Controvérsias aprovou o pedido brasileiro nos seguintes termos:

Na ocasião, foram também aprovados pedidos similares de Canadá, Coréia do Sul, Índia, Japão, México e União Européia. A autorização para "retaliar" não implica a obrigação do exercício desse direito, que continuará valendo enquanto a Emenda Byrd permanecer em vigor. (ITAMARATY, 2011).

Nota-se que a existência da legislação $A D$ propos modificações nos resultados do mercado, no que concerne a criação e indução ao comportamento estratégico, no âmbito das organizações, assim como pelas instituições. Essa abordagem permite observar que essa política induz algumas empresas a atuarem ou até desenvolverem um comportamento anticompetitivo, visto que a solicitação de uma investigação de dumping, por parte de uma empresa local, torna-se uma ameaça para a empresa do exterior. Como forma de livrar-se dessa ameaça, a emprea estrangeira é induzida a um acordo, que para ela será preferível ao risco de taxação do seu produto quando exportado para aquele país.

Muitas vezes, os países em desenvolvimento abrem mão do direito de "retaliar" ou sobretaxar, por não terem uma política definida para tal, principalmente quando o produto envolvido é essencial para a indústria nacional, ou até mesmo para o país. Nesse caso, uma retaliação ou fixação de uma taxa, só agrava a situação, pois o reflexo será sentido no preço final de consumo.

\footnotetext{
${ }^{5}$ Com relação a "Emenda Birdy", a CITAC (2011) já solicitou a revogação ou modificação dessa emenda, no sentido de enquadrá-la no cumprimento da legislação da Organização Mundial do Comércio (OMC) em 2003 a OMC reconheceu que a "Emenda Byrd" viola o acordo internacional e cria distorções no comércio entre os países signatários. Assim como, incentiva a apresentação de mais ações antidumping e medidas compensatórias, como forma de gerar fundos para os proponentes dessas ações.

${ }^{6}$ Método de cálculo utilizado pelo Departamento de Comércio Americano (DOC) na constatação de dumping. Segundo a OMC (2011) o método de zeramento, consiste em uma violação as regras do comércio internacional, um método inconsistente e, portanto, não deveria ser utilizado. Mesmo após derrotas na OMC, inclusive para o Brasil e envolvendo o método "Zeroing", o DOC ainda não deixou de utilizá-lo.
} 
É fundamental para o Brasil, o fortalecimento da estrutura de apoio estratégico nos bastidores junto a OMC, no Órgão de Solução de Controversia (OSC). Em 2007, o Brasil contava com aproximadamente 20 pessoas (16 diplomatas e três estágiarios sediados em Genebra) envolvidas no processo de controvérsias, entre outros. Além disso, o país contava, ainda, com um modesto auxílio técnico da iniciativa privada. Em contrapartida, o Departamento de Comércio dos Estados Unidos, no mesmo período, possuía 200 colaboradores exclusivos na OMC e mantinha conexão com 54 agência do governo federal e do Congresso, totalizando, aproximadamente, 600 pessoas que atuavam na Organização Mundial do Comércio. Ademais, os EUA recebiam apoio de centenas de instituições privadas. Já a União Européia, com o mesmo propósito, contava com o Departamento de Comércio da Comissão Européia, órgão que atuava em defesa do bloco, o qual era composto por 62 funcionários, atuando diretamente nas instituições burocráticas de cada país do bloco. Essa ligação criava um efeito multiplicador dos recursos disponíveis.

Mesmo diante da atuação da OMC, por intermédio do Órgão de Solução de Controvérsia (OSC), é possivel observar, que as grandes potências econômicas, em algum momento, atuam de forma paralela na defesa de seus interesses, utilizando-se, para isso, do seu poder econômico. A evidência desse fato é comprovada quando um país decide sofrer a retalhação imposta pelo OSC, à rever sua posição de comércio, considerada desleal com outro país membro. Diante disso, observa-se que a punição "antidumping" para essa atitude é branda ou ineficiente. Para tanto, é fundamental encontrar uma forma de punição para as trapaças. Algo que inviabilize o descumprimento de um acordo. Esse tipo de oportunismo deve ser combatido por intermédio do fortalecimento do órgão regulador, nesse caso a OMC.

\section{Perfil dos três elos da carcinicultura da microrregião litoral de Aracati - CE}

Passando à análise e interpretação dos dados coletados por meio da pesquisa realizada com os três elos da cadeia produtiva do camarão em cativeiro, na microrregião litoral de Aracati - CE. Na sequência, damos início à apresentação dos resultados da pesquisa com o primeiro elo, composto pelos laboratórios de larvicultura, tendo como meio de coleta de dados, aplicação de questionários. Para melhor entendimento e análise das informações, o questionário está organizado a partir de cinco itens. Os gráficos, com os resultados dos questionários são apresentados ao final do texto, em função do espaço exíguo.

O item I - do questionário aplicado aos laboratórios de larvicultura com a finalidade de caracterizar, identificar e localizar o empreendimento. Registre-se que, 100\% dos pesquisados desse elo, estão localizados no município de Aracati - CE, um na localidade Lagoa do Mato e o outro em Canoa Quebrada.

O Item II - do questionário tem como proposta coletar os dados do informante. A questão 2 identifica a função exercida na empresa, nesse caso $100 \%$ dos entrevistados são funcionários. Já a questão 3 - aponta o grau de instrução do informante, destaca-se o nível superior completo para todos os informantes. Quanto à pergunta 4 - que se refere ao tempo em que o informante atua na atividade, observa-se que $50 \%$ dos pesquisados está entre seis e dez anos em atividade e $50 \%$ dos pesquisados está acima de 11 anos na atividade.

A partir do item III do questionário, buscou-se coletar informações quanto à estrutura do empreendimento, compreendendo os dados temporais de 2003 e 2010. Na questão 5 identificou-se a área total da propriedade onde está situado o empreendimento, destaca-se que em 2003, a área total ficou em 4,7 hectares, apresentando um crescimento de 10,64\% para o marco de 2010. Na pergunta 6, buscou-se um comparativo entre os dois período, com relação à extensão da área ocupada pelo empreendimento, observou-se um crescimento de 3,85\% de um marco para o outro.

A pergunta 7, verifica se houve aumento na quantidade de tanques de larvicultura, os quais são utilizados para a produção das pós larvas. As respostas mostram que, permaneceu inalterado. Contudo, na capacidade de produção por ciclo, objetivo da pergunta 8, registra-se um aumento de 8,70\%. Observa-se que apesar de não ter aumentada a quantidade de tanques de larvicultura, conseguiu-se uma maior eficiência de produção e melhoria nos índices de produtividade. Isso pode ser comprovado com a resposta obtida por meio da pergunta 9, onde registra-se que a produção média efetiva por ciclo, apresentou um crescimento médio de $26,11 \%$ entre os marcos pesquisados.

O item IV - do questionário, procurou obter informações em relação ao emprego. Este item foi organizado a partir de três perguntas. A questão 10 permitiu que se estabelecesse um comparativo entre os marcos de 2003 e 2010. As respostas apontam para a identificação de uma queda de 44,03\% nos 
postos de trabalho da larvicultura, essa queda é reflexo da situação das fazendas. Na questão 11, buscou-se identificar o número de prestadores de serviços temporários, tais como diaristas. Em 2003 foi identificado $0,30 \%$ de pessoas ocupando esse tipo de atividade dentro dos laboratórios, em relação ao número de funcionários com carteira assinada no mesmo ano. Os dados obtidos por meio da pergunta 12 mostram que não foi constatado pessoas atuando em outros tipos de modalidade de vínculos.

A questão 15 apresenta possíveis oscilações na produção nos marcos de 2003 e 2010. No ano de 2003, os laboratórios refletem o que aconteceu nas fazendas; pode-se citar: os fatores de doenças, dumping, início da redução de densidades das fazendas entre outros. Esses fatores provocaram oscilações na produção, durante certo período que teve início em 2005 e pode ser observado até 2007, com grande queda na produção, interferindo, inclusive, em outras áreas dentro da empresa. Registra-se um período de crise no setor, com a baixa produção, ocorrem demissões, que podem ser constatadas na resposta da questão 10 do Item IV, que apresentou mais de $49 \%$ na redução do quadro de pessoal entre os marcos pesquisados, levando praticamente ao fechamento dos laboratórios.

Somente a partir de 2008, algumas fazendas que estavam desativadas, reiniciaram a produção, em função do aumento da demanda interna e com isso, um novo ciclo de crescimento. É possível analisar que a localização dos laboratórios e a facilidade de acesso aos produtores locais, fez com que esses produtores preferissem as larvas dos laboratórios mais próximos; fenômeno justificado pela redução de custos, pela amenização do stress dos animais no transporte, contribuindo para um melhor resultado. As respostas mostram que em 2010, acontece uma sequência positiva do que ocorre na observação da questão anterior. Observa-se aumento de sobrevivência das larvas e consequente aumento da produtividade. Registra-se a recuperação do setor, principalmente, no quesito confiança na atividade, o que apresenta melhor resultados quanto ao comércio. É interessante retomar-se as questão 13 e 14, onde fica evidente o aumento na produção por ciclo de $8,70 \%$ bem como a elevação das vendas em $37,23 \%$, caracterizando um novo ciclo e a recuperação da atividade, ainda que tudo isso ocorra com recursos dos próprios empreendedores, conforme registram nos relatos e respostas ao questionário.

A questão 16 mostra que os ciclos de produção das fazendas foram ampliados, anteriormente (2003), os produtores produziam em média 2,5 ciclos por ano, em 2010 existiam fazendas com até 4 ciclos por ano, esse fenômeno gerou um aumento pela demanda, aliado ao aumento do número de viveiros conforme é possível constatar na questão 7 do item III, questionário aplicado nas fazendas.

Nessa condição, mesmo com a redução de camarão por $\mathrm{m}^{2}$, a demanda por pós larvas aumentou. Consequentemente a produção de pós larvas por ciclo ficou mais disputada pelos produtores. Os relatos mostram que para ser atendido é necessário que o produtor faça uma programação de mais de 30 dias, caso contrário corre o risco de ficar sem povoar seus viveiros e diminuir a produção anual e consequentemente, os lucros.

As questões 17 e 18 podem ser interpretadas por meio do cruzamento dos resultados obtidos, considerando que as mesmas buscam saber sobre queda na produção e possível baixa de produtividade por fatores externos. Os dados coletados mostram que no marco de $2003,100 \%$ dos empreendimentos registram que a produção e a produtividade foram afetadas pelos fatores doenças e redução de demanda, ressaltando que a queda ocorre a partir de 2004 até 2007, sendo que no marco de 2010, esse fatores não interferiam.

As questões 19 e 20 apontam para uma similaridade, considerando-se as respostas anteriores. No mesmo período de 2004 a 2007, as fazendas adotaram uma estratégia de baixar a densidade de povoamento de camarão por $\mathrm{m}^{2}$, e isso levou também os laboratórios a seguirem essa tendência do mercado consumidor, uma vez que, as pós larvas produzidas devem ser comercializadas em apenas 10 dias, caso contrário passam a interferir negativamente nos custos da operação. Em 2010 essa tendência foi seguida e como as fazendas passaram a praticar ciclos mais curtos de produção, com até 4 ciclos ao ano, aliado ao crescimento do número de viveiros nas propriedades em $55,1 \%$, conforme pode-se constatar no item III, questão 7.

A questão 21 foi formulada de forma objetiva, com a intenção de verificar os reflexos do elo em relação à ação antidumping. Observou-se que os reflexos ocorreram de forma sistêmica nos três elos. $O$ cruzamento dos dados obtidos nos três elos de produção, evidencia que os reflexos da ação antidumping foram negativos para o setor, bem como para o desenvolvimento da região. Ao cruzar as respostas das questões que tratam do número de empregos e demissões é possível observar que nos três elos houve redução, vale salientar que não é possível dizer qual dos fatores (antidumping, doenças, enchentes, desvalorização cambial) teve maior ou menor participação, mas todos contribuíram para 0 cenário apresentado. 
Observa-se que existe uma falta de percepção com relação ao problema do antidumping, uma vez que atualmente a desvalorização cambial está inviabilizando a exportação, como é possível observar no marco de 2010, a partir das questões 21 e 22. No entanto, o problema da sobretaxa não pode ser deixado de lado, como se constata nas questões relacionadas à produção na indústria.

É importante lembrar que o mercado dos EUA é um dos maiores nesse segmento (valor agregado), e as possibilidade de retorno das exportações certamente irão esbarrar no custo tarifário imposto pela OMC. Caso o Brasil tenha interesse em competir nesse mercado, a sobretaxa inviabiliza essa possibilidade, pois a competição com os países asiáticos e com o México torna-se inviável, uma vez que esses, apresentam custos de produção menores que o Brasil.

O que torna o custo de produção na Ásia e no México menores do que o custo de produção no Brasil, não é a eficiência desses países em relação a produção e produtividade, tal fator decorre das condições socioeconômicas e de subsídios governamentais. Diante disso, a atividade da carcinicultura no Brasil não pode ficar em uma posição reativa, o setor deve ter uma atitude proativa em relação a esse problema, uma delas, pode ser o investimento em pesquisa e desenvolvimento, elaboração de novos produtos e prospecção de novos mercados, sem, contudo, esquecer de observar o comportamento do consumidor nacional. Nesse caso, uma boa alternativa para o setor, seria a organização de toda a cadeia produtiva, criar estratégias de atuação coletivas, de início, a formação de uma cooperativa para comercializar a produção, aquisição de insumos, equipamentos e serviços para todos os cooperados.

\begin{tabular}{|c|c|}
\hline Resultado para 2003 & Resultado para 2010 \\
\hline $\begin{array}{l}\text { 10 Problema com a liberação de licenças nos } \\
\text { órgãos ambientais. }\end{array}$ & $\begin{array}{l}\text { 1 Problema com a liberação de licenças nos } \\
\text { órgãos ambientais }\end{array}$ \\
\hline $\begin{array}{l}2^{0} \text { Falta de acesso aos incentivos financeiros } \\
\text { para o setor. }\end{array}$ & $\begin{array}{l}\text { 20 Ameaça de abertura das importações, atrelado } \\
\text { ao risco de doenças. }\end{array}$ \\
\hline $\begin{array}{l}3^{\circ} \text { Falta de uma política setorial, mais } \\
\text { especificamente voltada para a carcinicultura. }\end{array}$ & $\begin{array}{l}3^{\circ} \text { Falta de acesso aos incentivos financeiros para } \\
\text { o setor }\end{array}$ \\
\hline $\begin{array}{l}4^{0} \text { Doenças relacionadas a produção, queda na } \\
\text { produtividade. }\end{array}$ & $\begin{array}{l}4^{\circ} \text { Falta de uma política setorial, } \\
\text { especificamente voltada para a carcinicultura. }\end{array}$ \\
\hline $5^{\circ}$ Falta de pesquisa científica & $\begin{array}{l}5^{\circ} \text { Doenças relacionadas a produção, queda na } \\
\text { produtividade. }\end{array}$ \\
\hline 6을ão antidumping & $6^{\circ}$ Falta de pesquisa científica \\
\hline $\begin{array}{l}7^{0} \text { Fechamento das exportações, atrelado a } \\
\text { desvalorização cambial }\end{array}$ & $\begin{array}{l}7^{\circ} \text { Custo elevado da energia elétrica, e dificuldade } \\
\text { financeira para acessar os subsídios disponíveis. }\end{array}$ \\
\hline $\begin{array}{l}8^{\circ} \text { custo dos serviços, para liberação de } \\
\text { licenciamento, custos de exame físico químico, } \\
\text { solicitado para regularização de licenças. }\end{array}$ & \\
\hline
\end{tabular}

Quadro 3 - Relata por ordem de importância os maiores entraves para o desenvolvimento da carcinicultura.

Fonte: Resultados dos questionários da pesquisa de campo, 2011.

O quadro 3, apresenta os dados coletados a partir das respostas provenientes da última questão dos questionários aplicados em cada elo da cadeia, essa questão era comum para todos os elos. Sendo assim, todos os informantes tiveram a oportunidade de responder essa questão. Para maior entendimento do leitor, esclarecemos que para chegar ao resultado do quadro 3 fizemos as junções das respostas de todos os informantes dos questionários dos três elos, essa pergunta tem por objetivo solicitar para os informantes que relatem quais os maiores problemas enfrentados para 0 desenvolvimento da carcinicultura nos marcos de 2003 e 2010. Trata-se de uma questão aberta, para tratar dos dados obtidos com a referida questão, optou-se por organizar os dados no formato de quadro seguindo uma classificação por ordem de maior número de apontamentos por parte dos produtores. Para isso, contou-se com os pontos mais citadas com base nos relatos dos pesquisados dos três segmentos consultados, foi feita a junção das informações, e isso resultou na elaboração do quadro abaixo e respectivos resultados. 


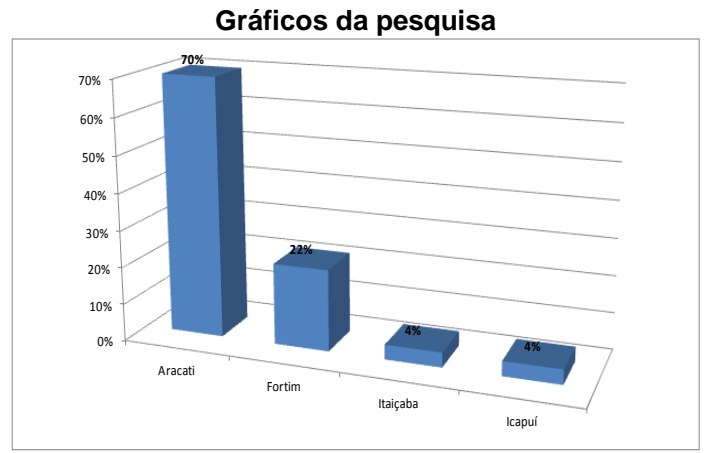

Gráfico 3 - Municípios da Microrregião Litoral de Aracati e a respectiva participação percentual na coleta de dados da pesquisa.

Fonte: Resultados dos questionários da pesquisa de campo, 2011.

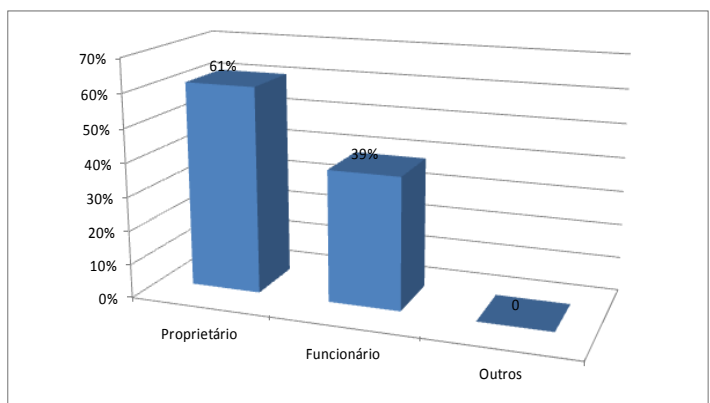

Gráfico 4 - Função exercida pelos informantes

Fonte: Resultados dos questionários da pesquisa de campo, 2011.

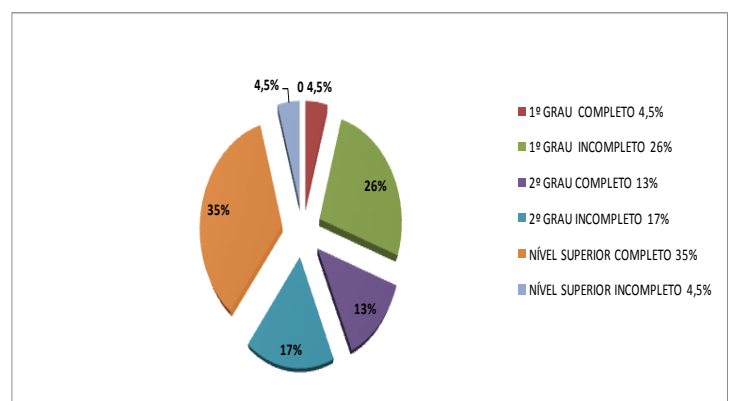

Gráfico 5 - Grau de instrução dos pesquisados.

Fonte: Resultados dos questionários da pesquisa de campo, 2011.

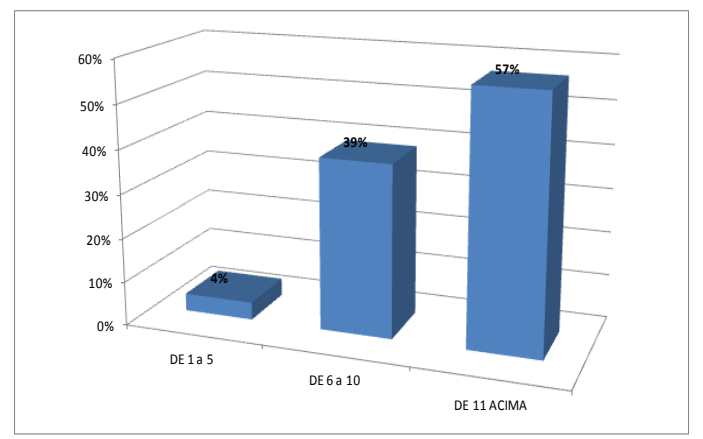

Gráfico 6 - Tempo de atuação do informante na atividade (anos)

Fonte: Resultados dos questionários da pesquisa de campo, 2011. 


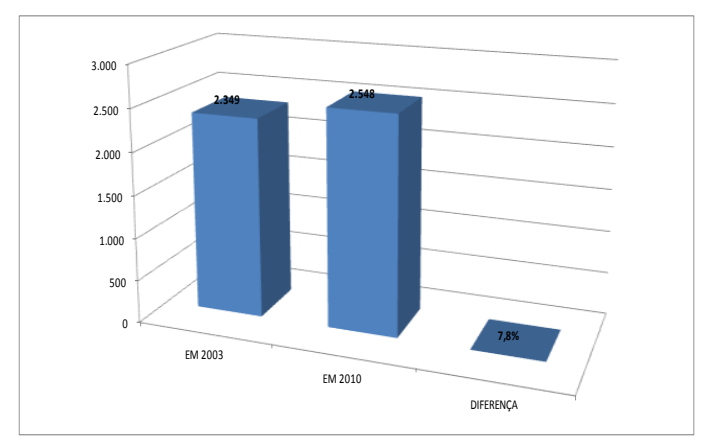

Gráfico 7 - Área total das propriedades em que foram aplicados os questionários nos marcos de 2003 e 2010 (em hectares).

Fonte: Resultados dos questionários da pesquisa de campo, 2011.

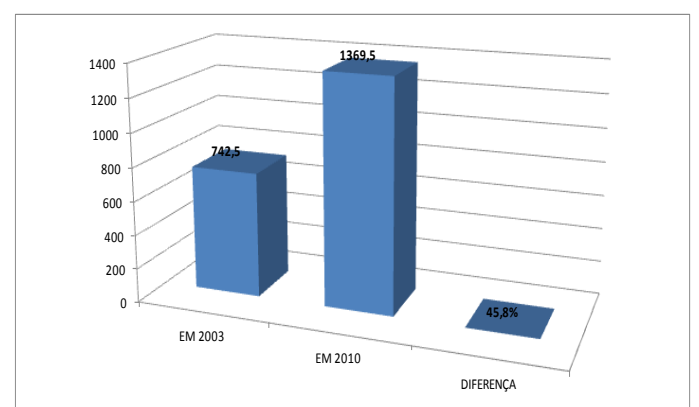

Gráfico 8 - Área total ocupada pelos empreendimentos nos marcos de 2003 e 2010 (em hectares)

Fonte: Resultados dos questionários da pesquisa de campo, 2011.



Gráfico 9 - Quantidade de viveiros de criação de camarão existente na propriedade nos marcos de 2003 e 2010 Fonte: Resultados dos questionários da pesquisa de campo, 2011.

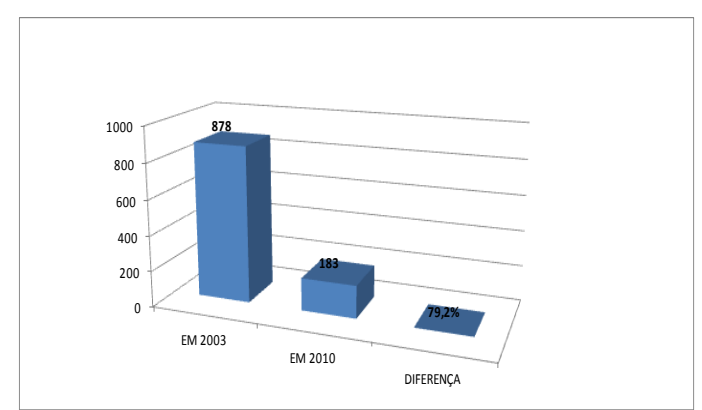

Gráfico 10 - Área de expansão dos viveiros nos marcos 2003 e 2010 (em hectares). Fonte: Resultados dos questionários da pesquisa de campo, 2011. 


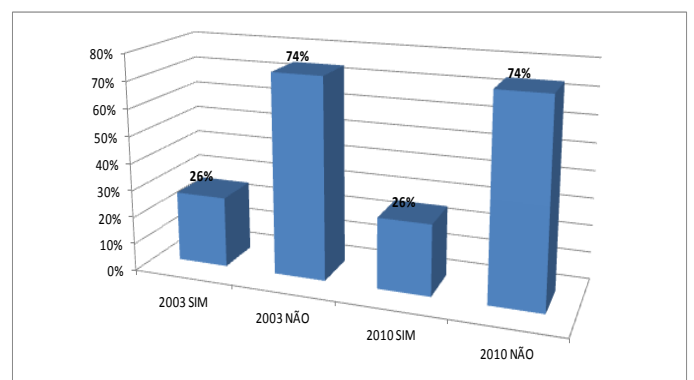

Gráfico 11 - Área ocupada por outras atividades na propriedade nos marcos de 2003 e 2010 (em hectares)

Fonte: Resultados dos questionários da pesquisa de campo, 2011

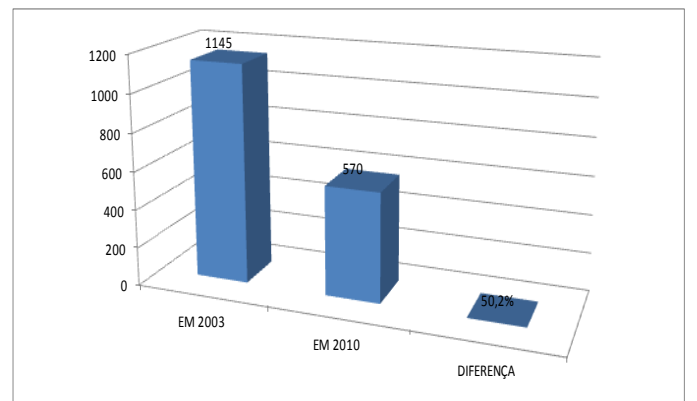

Gráfico 12 - Funcionários com carteira assinada nos marcos de 2003 e 2010

Fonte: Resultados dos questionários da pesquisa de campo, 2011.

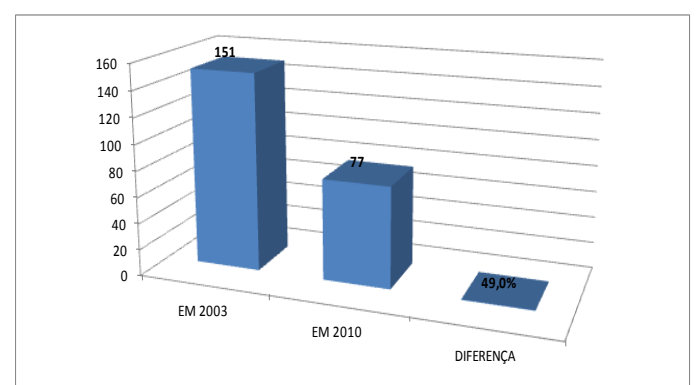

Gráfico 13 - Prestadores de serviço temporários nos marcos de 2003 e 2010

Fonte: Resultados dos questionários da pesquisa de campo, 2011.

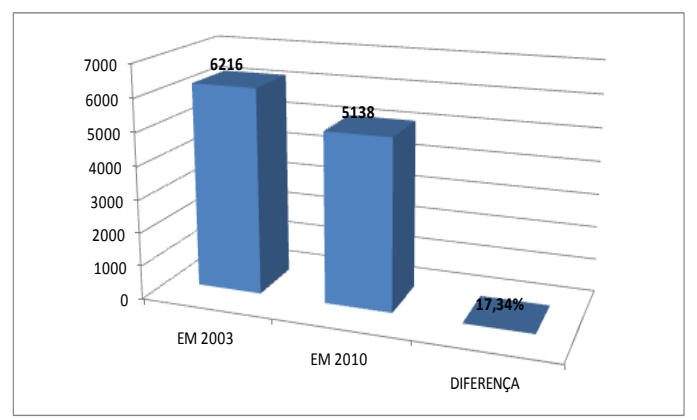

Gráfico 14 - Produção de camarão anual nos marcos de 2003 e 2010 (em toneladas) Fonte: Resultados dos questionários da pesquisa de campo, 2011. 


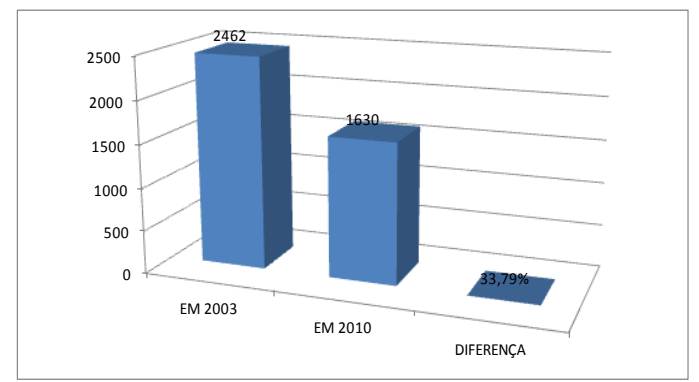

Gráfico 15 - Produção por ciclo nos marcos 2003 e 2010 (em toneladas)

Fonte: Resultados dos questionários da pesquisa de campo, 2011.

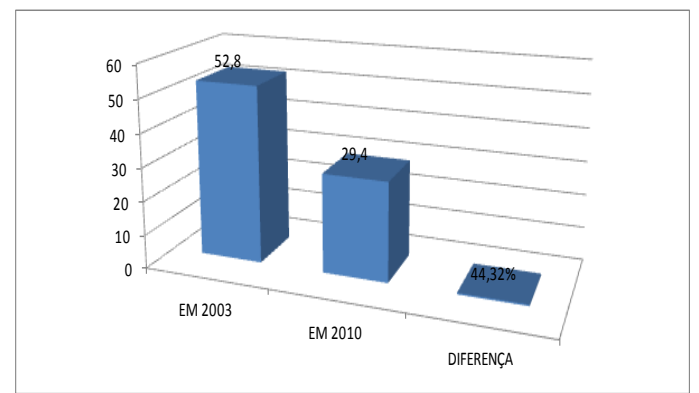

Gráfico 16 - Densidade média de povoamento dos viveiros por $\mathrm{m}^{2}$ nos marcos de 2003 e 2010.

Fonte: Resultados dos questionários da pesquisa de campo, 2011.

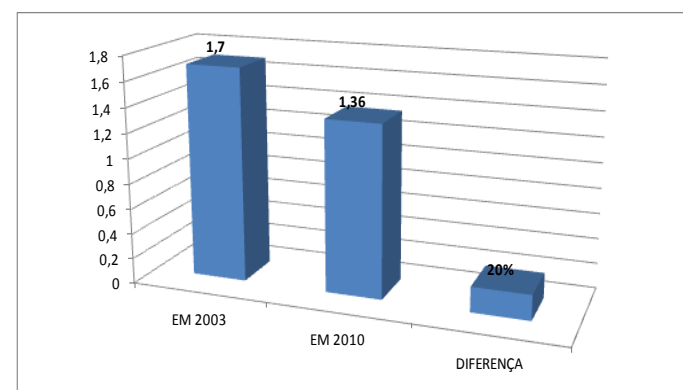

Gráfico 17 - Fator médio de conversão alimentar nos marcos 2003 e 2010. Fonte: Resultados dos questionários da pesquisa de campo, 2011.

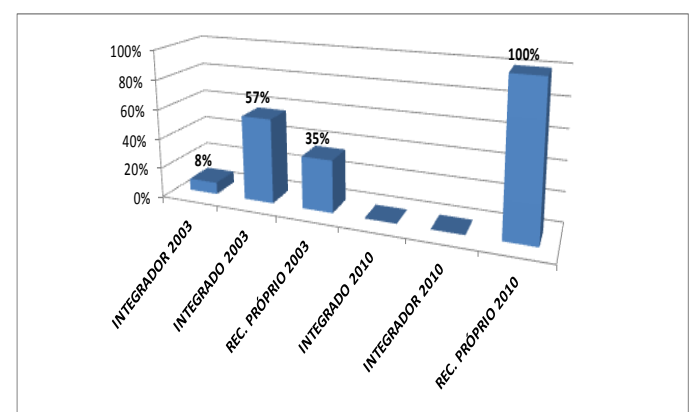

Gráfico 18 - Identifica em que condição o produtor está enquadrado nos marcos de 2003 e 2010. Fonte: Resultados dos questionários da pesquisa de campo, 2011. 




Gráfico 19 - Fornece o destino da produção de camarão em cativeiro nos marcos de 2003 e 2010. Fonte: Resultados dos questionários da pesquisa de campo, 2011.

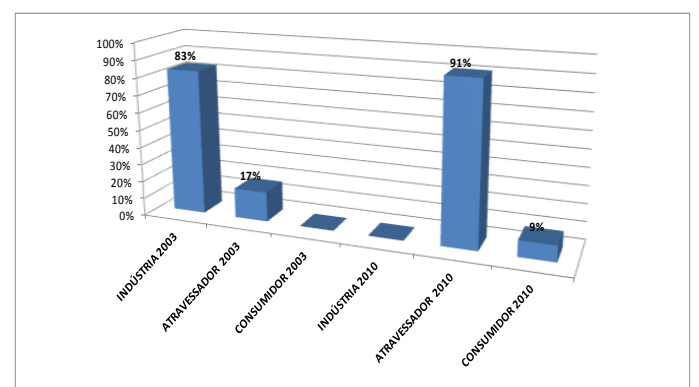

Gráfico 20 - Informa qual é o destino das vendas de camarão em cativeiro nos marcos 2003 e 2010. Fonte: Resultados dos questionários da pesquisa de campo, 2011.

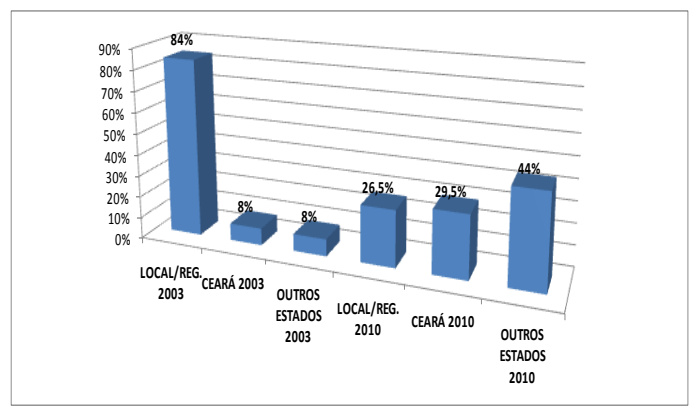

Gráfico 21 - Identifica a origem dos compradores do camarão para os marcos de 2003 e 2010. Fonte: Resultados dos questionários da pesquisa de campo, 2011.

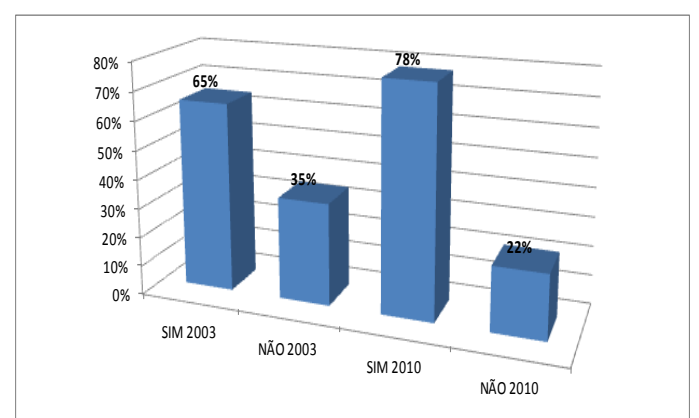

Gráfico 22 - Permite visualizar se a demanda por camarão superou a oferta nos marcos de 2003 e 2010. Fonte: Resultados dos questionários da pesquisa de campo, 2011. 


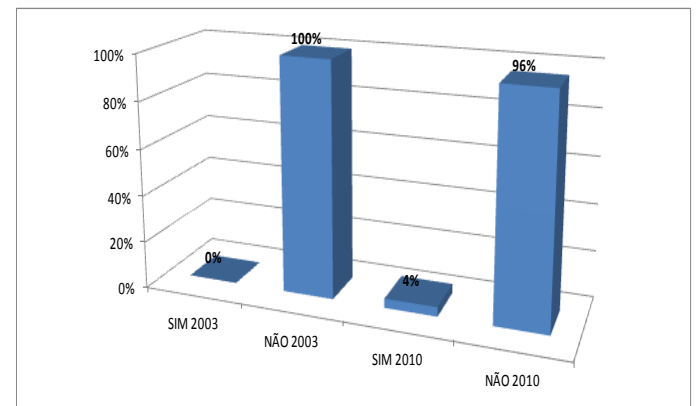

Gráfico 23 - O volume de produção foi afetado pela falta de compradores nos marcos de 2003 e 2010.

Fonte: Resultados dos questionários da pesquisa de campo, 2011.

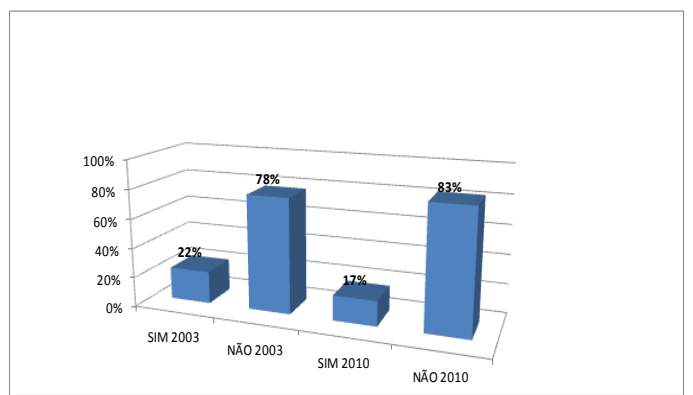

Gráfico 24 - O volume de produção foi afetado pela existência de doenças nos camarões nos marcos de 2003 e 2010. Fonte: Resultados dos questionários da pesquisa de campo, 2011.

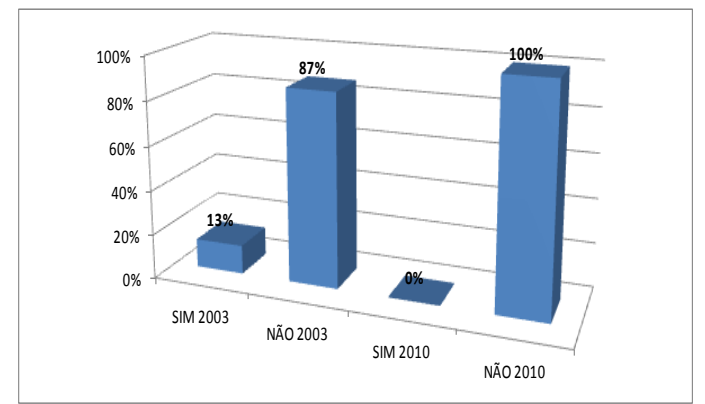

Gráfico 25 - A produção foi afetada por outros fatores nos marcos de 2003 e 2010.

Fonte: Resultados dos questionários da pesquisa de campo, 2011.

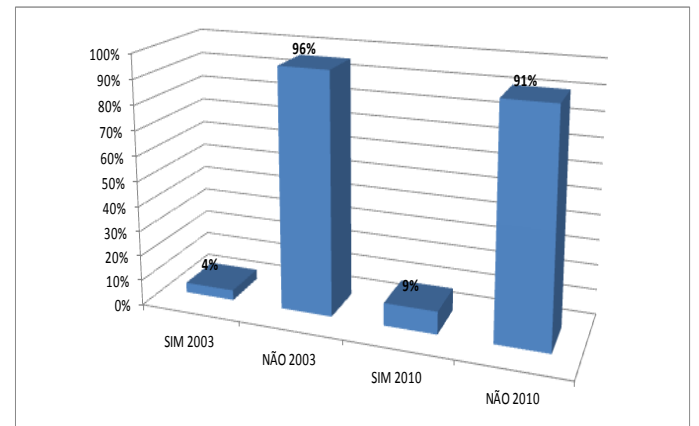

Gráfico 26 - Registrou-se queda na produção pela baixa demanda por parte dos compradores para os marcos de 2003 e 2010.

Fonte: Resultados dos questionários da pesquisa de campo, 2011. 


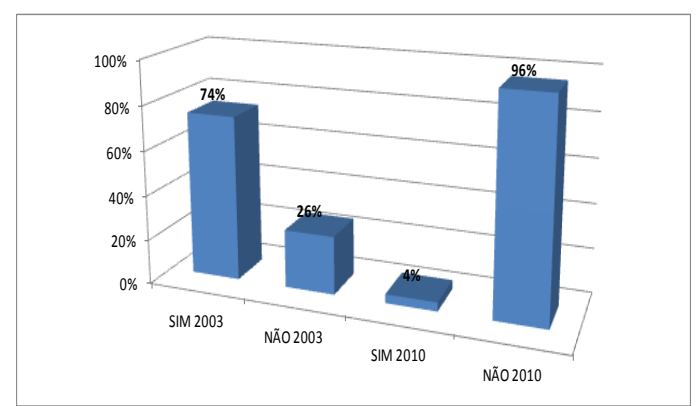

Gráfico 27 - A ação antidumping sofrida pela carcinicultura brasileira afetou sua forma de produção nos marcos de 2003 e 2010.

Fonte: Resultados dos questionários da pesquisa de campo, 2011.



Gráfico 28 - Houve redução na densidade de povoamento dos viveiros de criação de camarão nos marcos de 2003 e 2010. Fonte: Resultados dos questionários da pesquisa de campo, 2011.

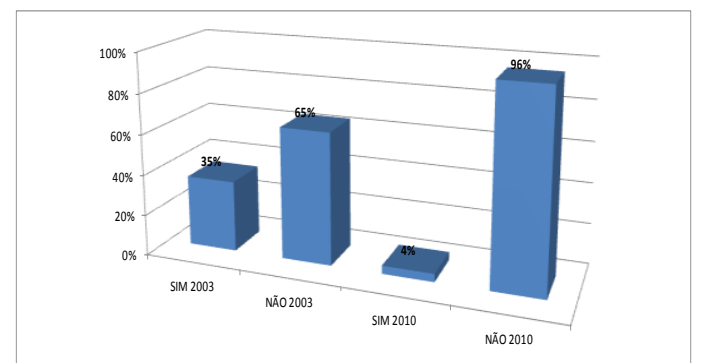

Gráfico 29 - Houve demissões em decorrência dos fatores: dumping, enchentes, doenças nos marcos de 2003 e 2010. Fonte: Resultados dos questionários da pesquisa de campo,2011.

\section{O mapa de localização da aquicultura no ceará}

Para analisar a importância relativa da aquicultura para os municípios do Estado do Ceará, propõe-se o uso do quociente locacional (QL), de maneira a identificar a existência de especialização/aglomeração na atividade produtiva.

De acordo com Haddad (1989, p. 245), a utilização de medidas de localização na formulação de políticas de descentralização industrial ou para conhecimento dos padrões regionais do crescimento econômico é frequente. "São medidas de natureza setorial e se preocupam com a localização das atividades entre as regiões", destaca-se ainda que buscam identificar padrões de concentração ou dispersão espacial do emprego setorial, em um ou mais períodos determinados.

Este mesmo autor observa que para calcular as medidas de localização e de especialização o ponto inicial é a organização dos dados em uma matriz, e em seguida é possível relacionar a distribuição setorial espacial de uma variável base. 


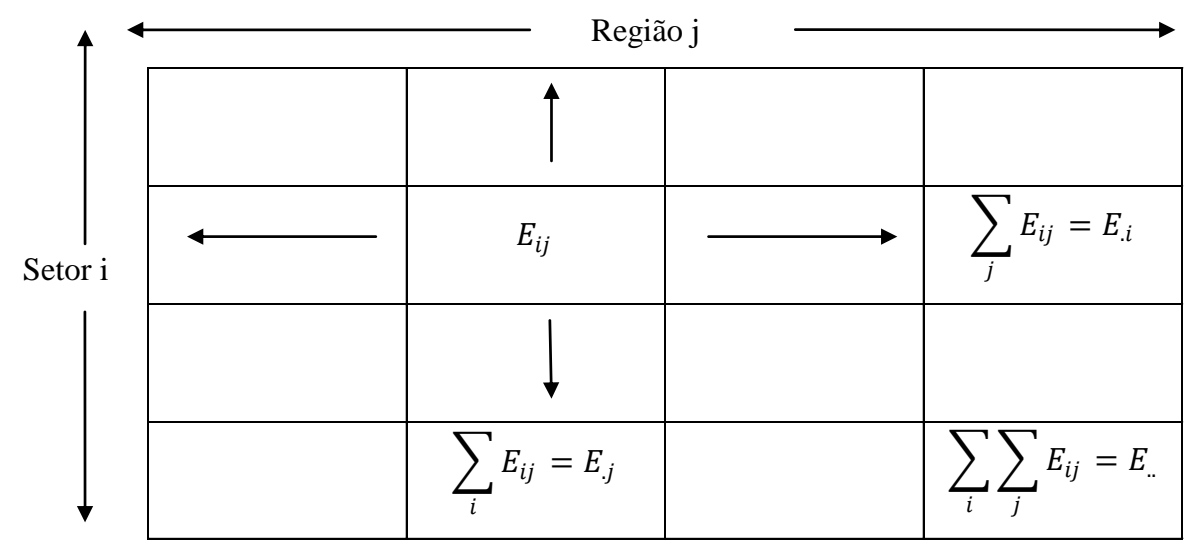

Quadro 1 - Matriz de Informações Fonte: Haddad (1989)

O uso da matriz proporciona a organização dos dados em linhas e colunas. Nas linhas observase como está distribuído o total de empregos em uma determinada indústria, setor ou atividade nos Estados. Nas colunas é possível observar como o total de empregos de uma referida região distribui-se entre as diversas atividades ou setores industriais.

Para o cálculo do QL são utilizados os dados do emprego formal da base de dados da Relação Anual de Informações Sociais (RAIS) no período de 2000 a 2010. Entre os motivos para a escolha desta variável destacam-se: maior disponibilidade de informações em nível de desagregação setorial e espacial; certo grau de uniformidade para medir e comparar a distribuição dos setores ou atividades no tempo. Nesse contexto, para o cálculo do QL no setor de aquicultura dos municípios do Ceará, utilizou-se a metodologia proposta por Hildebrand e Mace (1950):

$$
\left(Q L_{a_{j}}=\frac{\frac{E_{a_{j}}}{E_{a}}}{\frac{E_{j}}{E}}\right)
$$

Em que:

$E_{a j}=$ emprego formal na aquicultura do município $j$;

$E_{a .}=$ emprego formal na aquicultura do estado do Ceará;

$E_{. j}=$ emprego formal em todos os setores do município $j$;

$E$. . = emprego formal em todos os setores do estado do Ceará.

O quociente locacional compara a participação percentual de um município em um determinado setor, com a participação percentual do mesmo município no total do emprego para a economia do Estado de referência. O menor valor assumido pelo quociente locacional é zero, e ocorre quando o município não possui atividades no setor. Quando o valor do quociente estiver situado entre 0 e 1 significa que o setor não é relevante nessa atividade com relação ao estado de referência, ou seja, a atividade existe no município, mas não há especialização. Quando o valor do quociente for maior que 1, significa dizer que o município é relativamente mais importante, no contexto estadual, em termos do setor, do que em temos gerais de todos os setores, ou seja, há uma especialização do município no determinado setor produtivo

Neste propósito, Haddad (1989), aponta que quanto maior seu valor absoluto, maior o grau de especialização do município no setor correspondente, é comum atribuir escalas para os municípios especializados na produção. Assim, são considerados de "especialização baixa" os municípios com quociente locacional entre 1 e 5; "média especialização" os municípios com quociente locacional entre 5 e 10; e "alta especialização" os municípios com quociente locacional acima de 10. 
Os dados da Tabela 1, abaixo, mostram a importância da aquicultura para os municípios do Estado do Ceará, durante os anos de 2000 a 2010. Nota-se que, no primeiro ano da série, dos 184 municípios do Estado, 9 possuíam atividades ligadas à aquicultura, e desses, apenas 6 apresentaram QL maior que uma unidade, ou seja, 3,2\% dos municípios eram considerados especializados no setor.

\begin{tabular}{|c|c|c|c|c|c|c|c|c|c|c|c|}
\hline \multirow{2}{*}{$\begin{array}{l}\text { Quociente } \\
\text { Locacional }\end{array}$} & \multicolumn{11}{|c|}{ Número de municípios } \\
\hline & 2000 & 2001 & 2002 & 2003 & 2004 & 2005 & 2006 & 2007 & 2008 & 2009 & 2010 \\
\hline (1) Entre 0 e 1 & 3 & 4 & 7 & 7 & 9 & 11 & 5 & 12 & 10 & 13 & 12 \\
\hline (2) Entre 1 e 5 & 2 & 3 & 2 & 0 & 5 & 7 & 6 & 2 & 2 & 5 & 7 \\
\hline (3) Entre 5 e 10 & 0 & 2 & 3 & 6 & 4 & 4 & 5 & 5 & 4 & 5 & 8 \\
\hline (4) Maior que 10 & 4 & 7 & 9 & 7 & 5 & 7 & 10 & 10 & 13 & 10 & 8 \\
\hline $\begin{array}{l}\text { Total de municípios } \\
\text { produtores }(1+2+3+4)\end{array}$ & 9 & 16 & 21 & 20 & 23 & 29 & 26 & 29 & 29 & 33 & 35 \\
\hline $\begin{array}{l}\text { Total de municípios } \\
\text { especializados } \\
(2+3+4)\end{array}$ & 6 & 12 & 14 & 13 & 14 & 18 & 21 & 17 & 19 & 20 & 23 \\
\hline
\end{tabular}

\footnotetext{
TABELA 1: MUNICÍPIOS DO CEARÁ POR FAIXA DE QUOCIENTE LOCACIONAL NA AQUICULTURA, NO PERÍODO DE 2000 A 2010

Fonte: Elaborado pelo autor a partir dos dados da RAIS.
}

Conforme dados da tabela, observa-se que em 2001 dobrou o número de municípios especializados, e este permaneceu estável até 2004, quando houve um aumento no número de municípios produtores e especializados atingindo um pico em 2006 de 21 municípios (11,4\%) representativos na produção aquícola. A queda da importância relativa da aquicultura no total de municípios do Estado em 2007 pode ser explicada, em parte, pela redução da participação da carcinicultura no setor, decorrente da redução das exportações iniciadas em 2003.

No ano de 2010 registram-se 35 municípios com atividades ligadas à aquicultura, sendo 23 deles, ou $14 \%$ do total de municípios do Estado, especializados na produção, assim, comparando-se o ano de 2000 e o ano de 2010, houve um crescimento do número de municípios produtores e municípios especializados na ordem de $26 \%$. Os cinco municípios com maior QL, ou seja, maior especialização produtiva no último ano da série foram: Acarau $(86,45)$, Aracati $(60,76)$, Barroquinha $(46,76)$, Itaiçaba $(45,73)$ e Amontada $(17,26)$.

Essa evolução pode ser verificada nos mapas que apresentam o QL da aquicultura no Estado do Ceará de 2000 a 2010, conforme exposição abaixo. 


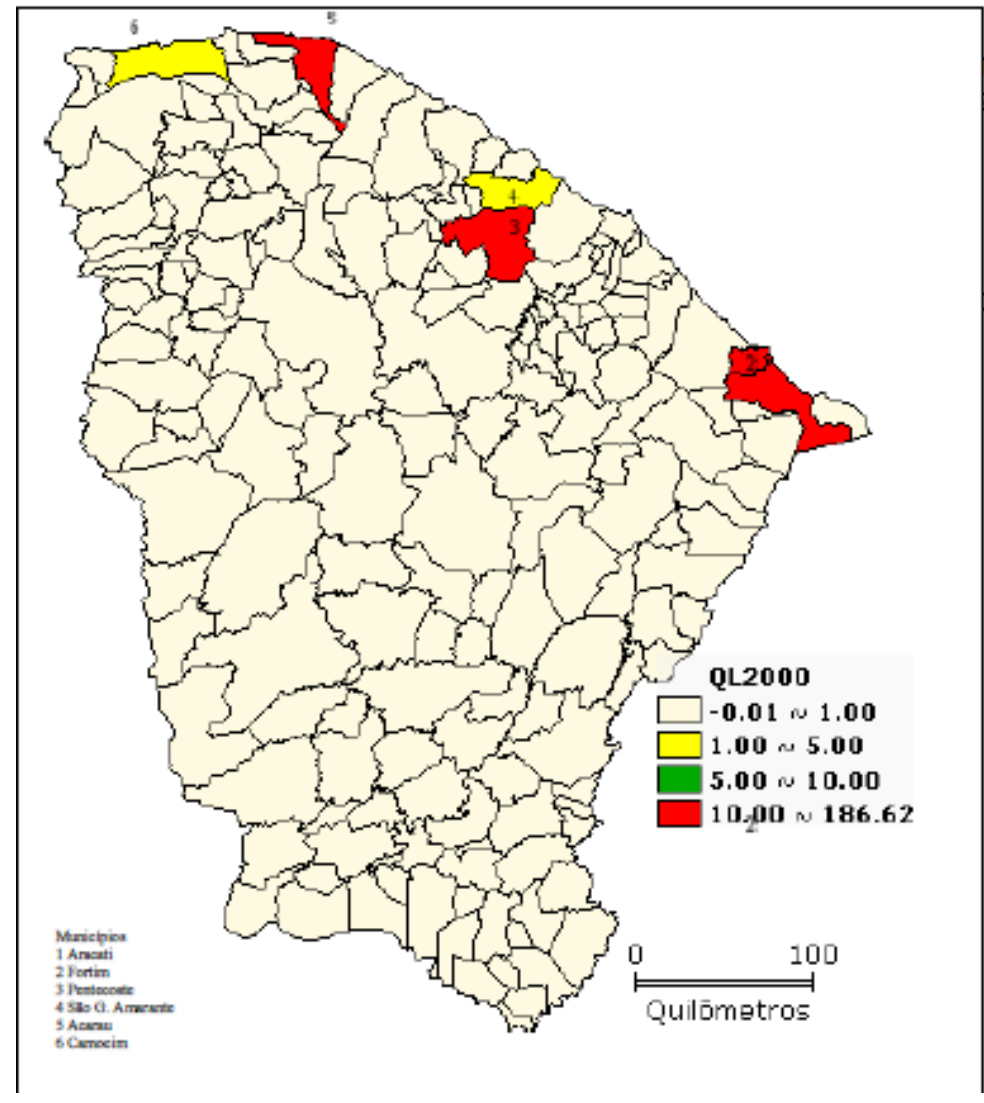

Mapa 1 - Quociente locacional: Grau de especialização setorial da localização da aquicultura no Estado do Ceará em 2000. Fonte: dados extraídos da RAIS 2011.

O mapa 1 apresenta os municípios ${ }^{7}$ com o maior grau de especialização medido pelo QL para o ano de 2000, ressalta-se que dos quatro municípios com alta especialização, três estão situados no litoral, Aracati, Acaraú e Fortim, sendo que o município de Pentecoste está localizado no semiárido nordestino. Ainda nesse contexto, destacamos os município de São Gonçalo do Amarante, e o município de Camocim com baixa especialização, os demais municípios do Estado, não são relevantes para a atividade de aquicultura, em relação ao Estado.

No mapa 2 constata-se que o L em 2001 apresenta uma evolução da participação da aquicultura em relação aos outros empregos no Estado do Ceará, para tanto, observa-se o aumento do número de municípios com alta especialização, nessa categoria, aparecem 7 municípios, é possível verificar que além daqueles já citados anteriormente no mapa de 2000, o município de Camocim, saiu da condição de média especialização e passou para alta especialização, assim como o município de Barroquinha e Beberibe, adquiriram diretamente o status de alta especialização, enquanto que, os municípios de Paraipaba e Jaguaruana, apresentam média especialização. Os municípios de Icapuí, Quixeré e Pedra Branca apresentam sinais de baixa especialização na atividade.

\footnotetext{
${ }^{7}$ Nos mapas 1, 2, 3, 4 e 5, os municípios estão numerados para identificação das cidades, esclarecemos que os municípios podem receber números diferentes em cada mapa, sendo assim, sugerimos que acompanhem sempre a legenda existente em cada um dos mapas.
} 


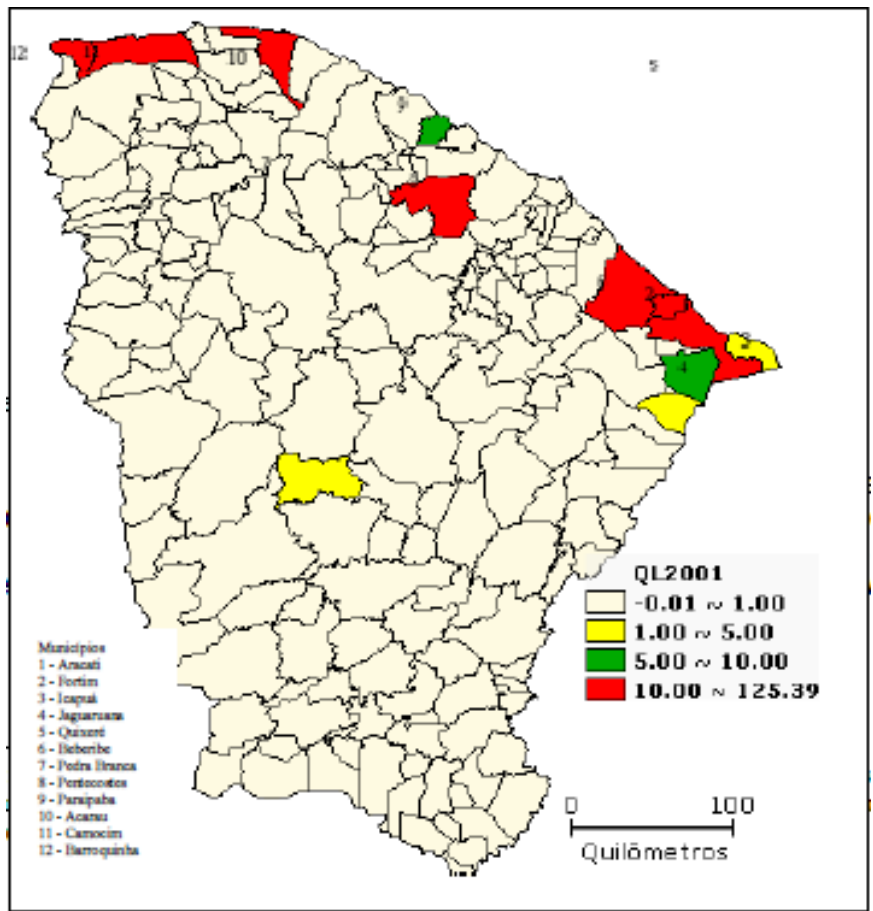

Mapa 2 - Quociente locacional: Grau de especialização setorial da localização da aquicultura no Estado do Ceará em 2001. Fonte: Dados extraídos da RAIS 2011.



Mapa 3 - Quociente locacional: Grau de especialização setorial da localização da aquicultura no Estado do Ceará em 2002. Fonte:Dados estraídos da RAIS 2011.

Quando observamos o mapa que retrata o período de 2002, fica evidente a ampliação da 
participação da atividade na geração de emprego do Estado, assim como é possível acompanhar a expansão da atividade nos municípios em relação às demais atividades. Na visualização do mapa de 2002, constatam-se três novos municípios na faixa de alta especialização, entre os quais se destacam Chaval, Granja e Paraipaba , assim como, Icapuí, Jaguaruana e Pentecostes, passaram a integrar a faixa de média especialização, já os municípios de Itaiçaba e Russas aparecem na faixa de baixa especialização, o que pode ser um indício da implantação da atividade naqueles municípios.

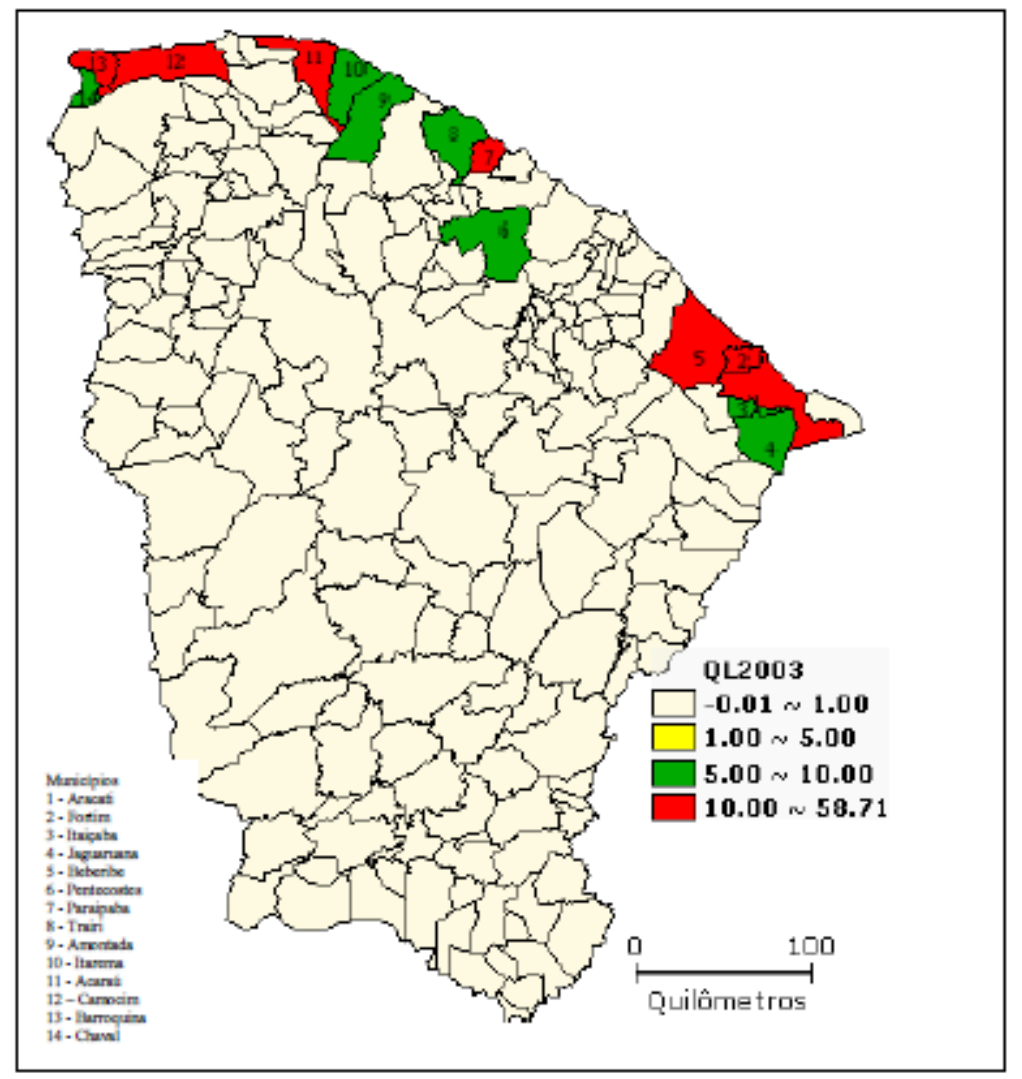

Mapa 4 - Quociente locacional: Grau de especialização setorial da localização da aquicultura no Estado do Ceará em 2003. Fonte: dados extraídos da RAIS 2011.

No mapa correspondente ao QL de 2003, observa-se que alguns municípios que anteriormente ocupavam a faixa de alta especialização, nesse cenário, aparecem como não relevantes para a 0 contexto setorial dentro do Estado. Ainda no cenário de 2003, existem 14 municípios em destaque, sendo que $50 \%$ na faixa de média especialização e 50\% com alta especialização. Esses municípios demonstram ter aptidão para a atividade, uma vez que nos próximos cenários até 2010, é possível observar, que eles ocupam sempre as faixas de média e alta especialização.

Considerando-se o foco da presente pesquisa, que visa estudar o desenvolvimento da aquicultura na microrregião Litoral de Aracati, nos marcos de 2003-2010, passamos a analisar o mapa do QL do ano de 2010, no contexto geral do Estado do Ceará e assim, disponibilizamos os demais mapas com o cálculo de QL em anexo. 




Mapa 05- Quociente locacional: Grau de especialização setorial da localização da aquicultura no Estado do Ceará em 2010. Fonte: dados extraídos da RAIS 2011.

Observa-se que, ao longo do tempo, alguns municípios demonstram ter maior aptidão para a atividade, conforme se verifica no mapa. A partir de 2003, os municípios que apresentam maior aptidão para a atividade são identificados no mapa, ocupando a segunda e a terceira faixa do QL, o que indica, para esses municípios, índices de especialização médios e altos na aquicultura para o Estado do Ceará. Observa-se também, que a atividade aparece com mais frequência em outros municípios que não estão ligados ao litoral. Por meio dessa referência, percebe-se que as técnicas de cultivo em água de baixa salinidade e doce estão progredindo no Estado, aspecto que afirma o potencial produtivo de várias regiões para a aquicultura, o que pode ser confirmado pela evolução de crescimento percentual entre 2000 e 2010, que ficou em $26 \%$ no Ceará.

Nesse contexto, conforme dados apresentados pelo presidente da ABCC, questionário anexo, registra-se que a interiorização da carcinicultura com a introdução do camarão $L$. vannamei, encontrou excelentes condições de adaptação às águas dos inúmeros reservatórios e rios perenes, existentes e distribuídos no interior de toda a Região Nordeste. Este dado abre uma nova e importante expectativa para a geração de renda e emprego nas áreas interioranas.

Sendo assim, é importante lembrar que políticas públicas para o desenvolvimento da atividade são necessárias, assim como desburocratizar os processos de legalização ambiental. É fundamental não confundir desburocratização com banalização dos processos, não é isso que a atividade está propondo, segundo relato dos produtores, eles almejam o reconhecimento da atividade e sua importância para 0 desenvolvimento regional.

De acordo com relatos do presidente a $A B C C$, obtidos a partir de questionário anexo a esta pesquisa, desde 2004 foram instituídos códigos: a) código de boas práticas de manejo para maturação, reprodução e larvicultura de camarão marinho; b) código de conduta e de boas práticas de fabricação, para fabricantes de ração para camarão; c) código de conduta e de boas práticas de manejo para uma carcinicultura ambientalmente sustentável e socialmente responsável; d) código de conduta para indústrias de beneficiamento de camarão marinho. Dados desse questionário revelam ainda, a criação do selo verde, com compromisso, social, ambiental e de segurança alimentar, envolvendo toda a cadeia de produção do camarão em cativeiro.

Um dos elementos importantes para o reconhecimento da atividade e sua legalidade no Estado e 
consequentemente, as contribuições em nível nacional e internacional passa pela institucionalização e a criação de normas que possam gerenciar conflitos no atual contexto econômico.

É importante considerar além da legalização da atividade, a contribuição da tecnologia. Relatos do presidente a $\mathrm{ABCC}$, obtidos a partir de questionário anexo a esta pesquisa, indicam que o Brasil conta com uma tecnologia de produção sustentável, consolidada e adaptada às condições do contexto brasileiro. O presidente a $A B C C$ se refere a esse processo reconhecendo-o como patrimônio nacional em termos de pesquisa e desenvolvimento. As técnicas de maturação e larvicultura, melhoramento genético dos plantéis de reprodutores, desenvolvidas e disseminadas entre as empresas especializadas garantem o suprimento da demanda de pós-larvas. É preciso que se diga que a comprovação científica de métodos e critérios essenciais de manejo da produção e de processamento asseguram a qualidade do produto final, de forma que, o modelo de produção, do ponto de vista tecnológico, atende as demandas atuais do setor.

Dados obtidos, a partir desse questionário, indicam que o mercado brasileiro está consumindo um produto com padrão de qualidade internacional, sem desconsiderar o cuidado e o respeito ambiental, conforme demonstram os estudos realizados por Madrid ${ }^{8}$, (2004), em pesquisa de pós-doutoramento, intitulada Influencia do Meio Ambiente em Áreas de Risco na Qualidade Bacteriológica do Camarão Cultivado no Estado do Ceará, realizada no LABOMAR, Universidade Federal do Ceará. O pesquisador afirma:

[...] de forma geral pode-se dizer que, estatisticamente, a água de drenagem do viveiro em termos microbiológico é mais limpa que a água de abastecimento das fazendas, o que se permite deduzir que os viveiros de camarão atuam como piscinas de estabilização e depuração de efluentes. Isso, com base no fato de que o referido estudo constatou que a contaminação de coliformes totais e coliformes fecais da água dos viveiros de camarão foi reduzida em 30 e $35 \%$, respectivamente. Quando comparada com a água de captação. (MADRID, 2004, p.132).

Nessa perspectiva, a prática da atividade torna-se sustentável, pois o amparo legal somado ao emprego de tecnologias adequadas minimiza os impactos da atividade no meio ambiente, contribuindo para uma imagem positiva da carcinicultura incentivando o desenvolvimento da atividade em áreas costeiras.

O presidente da $A B C C$ informa por meio dos dados do questionário, sobre outro trabalho de pesquisa realizado pelo Instituto de Ciências do Mar, LABOMAR, da Universidade Federal do Ceará, em parceria com a Sociedade internacional para Ecossistemas de manguezal (ISME). Esse trabalho referese ao Estudo das Áreas de Manguezais do Nordeste do Brasil, em que o autor identifica que entre 1978 a 2004, a área de mangues nos 5 Estados estudados, cresceu $36,11 \%$, o que indica a sustentabilidade do setor com relação aos manguezais. Dados mais completos sobre essa pesquisa encontram-se em Maia et al (2005).

A partir dos dados coletados que dão suporte às reflexões sobre o mapa de localização da aquicultura no Ceará, observa-se a existência de ações, por parte da ABCC e do setor, para a resolução de conflitos existentes na atividade, tornando-a sustentável. Evidencia-se necessidade do fortalecimento de políticas públicas setoriais que visem promover o desenvolvimento regional.

\section{Considerações finais}

Nesse trabalho, tomou-se como marco o ano de 2003, em que os produtores de camarão do Brasil, China, Tailândia, Índia, Vietnã e Equador, foram alvo de investigação de prática de dumping, movida pela Sociedade Sulista de Pescadores de Camarões (SSA) e a pela Associação de Pescadores do Estado da Luisiana, dos Estados Unidos. A partir de então, a ação antidumping sobre a carcinicultura no Brasil evidência quatro fases distintas.

Primeiramente registra-se que em julho de 2004, o Brasil foi condenado em um percentual que variou de $0 \%$ a $67,8 \%$. Em uma segunda fase, propriamente agosto de 2004, a Empresa de Armazenagem Frigorífica (EMPAF), que anteriormente não era taxada foi penalizada com taxas de $12,86 \%$, chegando a uma média de $23,66 \%$. Num terceiro momento, em dezembro de 2004 , a margem antidumping foi reduzida para 10,4\%. E por fim, um último recurso da ação antidumping, registrado em

\footnotetext{
${ }^{8}$ Pesquisador analista ambiental do IBAMA-CE.
} 
janeiro de 2005, verifica que o camarão produzido em cativeiro no Brasil e exportado para os Estados Unidos foi sobretaxado a $7,05 \%$.

Sabe-se que o processo antidumping inclui revisões anuais por parte do DOC, registra-se que em 2006, conforme já discutido nessa dissertação, foram selecionadas pelo DOC duas empresas brasileiras para serem investigadas, de um grupo maior de exportadores brasileiros listados para revisão pelos peticionários, sendo que para duas empresas investigadas, o DOC aplicou taxas individuas, e para as demais empresas desse grupo, fixou uma nova tarifa. A partir de 2006, passou a existir uma série de taxas individuas para empresas investigadas, assim como, a fixação de taxas punitivas para as empresas que não colaboraram com as investigações.

De 2008 a 2010, pelo fato de não ter havido importações oriundas do Brasil, não houve taxa a revisar. Ressalta-se, que a taxa original de $7,05 \%$ continuou vigorando para todas as empresas que não foram listadas para a revisão em 2006 e 2007, e para novas empresas que vierem a exportar para os Estados Unidos no futuro.

O cruzamento de dados obtidos por meio dos questionários aplicados nos três elos da produção, assim a análise do coeficiente locacional evidenciou que os reflexos da ação antidumping foram negativos para o setor, bem como para o desenvolvimento da região. A interpretação dos dados que se referem ao número de empregos e demissões mostrou que o setor perdeu $50 \%$ dos postos de trabalho, contudo não é possível afirmar exatamente quais fatores (antidumping, doenças, enchentes, desvalorização cambial) influenciaram em maior ou menor grau, contudo, é fato que todos esses fatores contribuíram para a redução do emprego na microrregião.

Com relação às fazendas de produção, verificou-se que a ação antidumping afetou a forma de produção. Os dados coletados mostraram que após o ano de 2003, a produção da carcinicultura esteve voltada para um modelo de produção integrada, com foco na exportação, e uma atuação mínima no mercado interno. Esse fato influenciou nas baixas de produção da indústria, considerando que tais indústrias possuem investimento em um ativo específico.

Os dados coletados apontaram que a investigação de dumping pelos EUA instalou um clima de incerteza na carcinicultura brasileira influenciando na continuidade das exportações. Nesse contexto da ameaça da ação antidumping, a exportação para a Europa foi intensificada, permitindo que os importadores europeus agissem de forma oportunista, baixando o preço do camarão brasileiro, com a argumentação embasada no aumento da produção procedente do continente asiático, fato somado à desvalorização cambial que inviabilizou a exportação de camarão.

Nesse contexto, as empresas integradoras perderam o interesse em manter seus contratos de integração, levando os produtores a encerrarem suas atividades por falta de recursos financeiros para manter-se na atividade. Registra-se que outros produtores passaram a produzir com recursos próprios. Uma forma encontrada pelos produtores para reduzir custos e melhorar o fator de sanidade dos viveiros consistiu em diminuir a densidade nos povoamentos.

Registra-se que essa estratégia de redução da produção gerou dificuldade de liquidez, forçando o refinanciamento das dívidas rurais, tendo direito a esse benefício, aqueles produtores que foram afetados por doenças ou ação antidumping. Nesse contexto, a insegurança gerada pela ação antidumping obrigou os produtores a buscarem novas alternativas de comercialização, encontrando no mercado interno boa receptividade.

Os dados coletados apontaram como um grande problema, a questão da dificuldade para os produtores conseguirem a renovação ou aquisição da licença ambiental. A esperança entre os produtores é que o novo código florestal seja aprovado e permita a expansão da atividade no Estado, considerando que o aprimoramento da tecnologia de cultivo do camarão em água de baixa salinidade e água doce permite que novas propriedades possam ter na carcinicultura uma nova perspectiva de exploração econômica.

É interessante registrar que os dados obtidos por meio dos questionários, nos três elos da cadeia produtiva mostram que há uma preocupação maior entre os produtores com relação à dificuldade na obtenção de licenças ambientais, colocando em segundo plano a preocupação com relação ao problema do antidumping.

Com relação à indústria, a falta de maior percepção do problema do antidumping pode ser um agravante, considerando que a sobretaxa não pode ser ignorada, uma vez que existe uma tendência contemporânea de produzir com valor agregado e essa tendência se apresenta de forma promissora. É importante lembrar que o mercado dos EUA é um dos maiores consumidores nesse segmento de valor agregado. 
Considerando o potencial da atividade da carcinicultura no Estado do Ceará, e consequentemente, o potencial da referida atividade para o desenvolvimento regional brasileiro, ressaltase a importância da institucionalização do comércio internacional, em especial, observa-se que a criação de regras gerais para a regulamentação do comércio internacional ganha forças a partir da criação da OMC, uma vez que esta organização normatiza o sistema de comércio entre os países e garante fórum neutro para dirimir as questões polêmicas nos contratos de comércio entre nações.

No contexto da OMC, a legislação antidumping tem como função proteger a indústria nacional, pois combate comportamentos considerados transgressores às regras e costumes praticados pelo comércio internacional. Registra-se que o Brasil também possui uma legislação que dispõe sobre a aplicação dos direitos previstos no acordo antidumping, conforme já discorrido no interior desta dissertação.

Dados coletados por meio de questionário com o presidente da $A B C C$ apontaram a inexistência de apoio institucional por parte dos órgãos responsáveis na contenda entre o Brasil e os Estados Unidos. A falta de maior empenho dos órgãos governamentais com relação à atuação no processo da ação antidumping acarretaram prejuízos econômicos para a atividade, além de prejuízos de ordem política, ao considerar-se o atraso da participação do país no processo.

De acordo com dados apresentados pelo presidente da $A B C C$, o setor está tomando a iniciativa de buscar a sustentabilidade da atividade ao propor a criação dos Códigos de conduta desde 2004, a citar: a) código de boas práticas de manejo para maturação, reprodução e larvicultura de camarão marinho; b) código de conduta e de boas práticas de fabricação, para fabricantes de ração para camarão; c) código de conduta e de boas práticas de manejo para uma carcinicultura ambientalmente sustentável e socialmente responsável; d) código de conduta para indústrias de beneficiamento de camarão marinho.

Nesse sentido, reforça o compromisso social dos códigos aqui descritos, a criação do selo verde, ao amparar a sustentabilidade de toda a cadeia de produção do camarão em cativeiro.

Em função das conclusões da pesquisa como um todo, ficam evidentes algumas perspectivas e desafios que demandam atenção especial, sendo principalmente: a) implementação de políticas de apoio aos grandes empreendimentos e políticas de inclusão social com a incorporação do pequeno produtor à atividade; b) apoio à interiorização da carcinicultura com o camarão L. vannamei, adaptado às águas dos reservatórios e rios perenes; c) consolidação de órgãos públicos voltados ao setor, a exemplo do Ministério da Pesca e Aquicultura e a Lei de Aquicultura e Pesca e criação do novo Código Florestal. Adicionalmente, cita-se a criação da Embrapa - Aquicultura, no contexto da Lei que criou o MPA, abrindo uma nova perspectiva para a geração e distribuição de tecnologias para o setor aquícola brasileiro.

\section{Referências}

ABCC. Associação Brasileira dos Criadores de Camarão. A carcinicultura brasileira em 2003. Disponível em: <http://www.abccam.com.br/download/carci03.pdf> Acesso em: 02/10/2010.

Estatísticas do setor pesqueiro e da Carcinicultura Brasileira. Disponível em: <http://www.abccam.com.br/abcc/images/stories/estatisticas/Estatstica_DO_SETOR_PESQUEIRO.pdf>. Acesso em: 05/08/2010

Documentos. Análise da Balança Comercial, das Potencialidades e dos Entraves Confrontados pelo Setor Pesqueiro Brasileiro, com Destaque para a Carcinicultura Marinha. Disponível <http://www.abccam.com.br/abcc/images/stories/documentos/analise_dA_BALANA_COMERCIAL.pdf>. Acesso em 18/10/2011. PUBLICAÇÕES. ANALISE DA PRODUÇÃO. ROCHA, Itamar, P; ROCHA, D, M. Analise da produção e do mercado interno e externo do camarão cultivado. Disponível em:< http://www.abccam.com.br/abcc/publicacoes>. Acesso em 09/08/2011.

CITAC. COALIZÃO DA AÇÃO COMERCIAL DAS INDÚSTRIAS DE CONSUMO. Disponível em: $<$ http://www.citac.info/shrimp/about/byrd_amendment.htm>. Acesso em 05/09/2011.

ITAMARATY Ministério das Relações Exteriores. Disponível em: <http://www.itamaraty.gov.br/sala-deimprensa/notas-a imprensa/2004/11/26/decisao-da-omc-favoravel-ao-brasil-sobre-a-emenda>. Acesso em 10/09/2011. 
. Camarão - Mercado Americano: ação antidumping, política de preços e tendência de demanda.

LABOMAR/UFC, Documentos Ocasionais, n. 3, Fortaleza, 2006. Disponível em: <http://www.gipescado.com.br/arquivos/camarao_usa.pdf>. Acesso em 01/06/2011.

MDIC/SECEX. MINISTÉRIO DO DESENVOLVIMENTO, INDÚSTRIA E COMÉRCIO, Portarias da
Secretaria de Comércio <http://www.mdic.gov.br/sitio/interna/interna.php?area=1\&menu=3113\&refr=1695>. Acesso em 2011.

NMFS. NATIONAL MARINE FISHERIES SERVICE. Divisão de Estatísticas do National Marine. Disponível em: <http://www.nmfs.noaa.gov/fishwatch/trade_and_aquaculture.htm>. Acesso em 01/09/2011.

NOAA. NATIONAL OCEANIC AND ATMOSPHERIC ADMINISTRATION. Disponível em: <http://www.nmfs.noaa.gov/fishwatch/species/pink_shrimp.htm\#>. Acesso em 01/09/2011.

OMC. ORGANIZAÇÃO MUNDIAL DO COMÉRCIO. Glossário. Disponível em: <http://www.wto.org/english/thewto_e/glossary_e/zeroing_e.htm>. Acesso em 06/09/2011.

ROCHA, I. P. Carcinicultura brasileira: desenvolvimento tecnológico, sustentabilidade ambiental e compromisso social. Revista da ABCC, Recife, ano 9, set. 2007.

TAHIM, Elda, Fontinele. Inovação e meio ambiente: o desafio dos arranjos produtivos de cultivo de camarão em cativeiro no Estado do Ceará. 2008, p.169 e 170. Dissertação de Mestrado - Rio de Janeiro: UFRJ/IE. 